Article

\title{
Kinetic Parameters of Nut Shells Pyrolysis
}

\author{
Tomasz Noszczyk $^{1} \mathbb{D}$, Arkadiusz Dyjakon ${ }^{1, * \mathbb{C}}$ and Jacek A. Koziel ${ }^{2} \mathbb{D}$ \\ 1 Department of Applied Bioeconomy, Wroclaw University of Environmental and Life Sciences, \\ 51-630 Wroclaw, Poland; tomasz.noszczyk@upwr.edu.pl \\ 2 Department of Agricultural and Biosystems Engineering, Iowa State University, 4350 Elings Hall, \\ Ames, IA 50011, USA; koziel@iastate.edu \\ * Correspondence: arkadiusz.dyjakon@upwr.edu.pl
}

check for

updates

Citation: Noszczyk, T.; Dyjakon, A.; Koziel, J.A. Kinetic Parameters of Nut Shells Pyrolysis. Energies 2021, 14 , 682. https://doi.org/

10.3390/en14030682

Academic Editors: Changkook Ryu and Javier Fermoso

Received: 8 December 2020

Accepted: 23 January 2021

Published: 28 January 2021

Publisher's Note: MDPI stays neutral with regard to jurisdictional claims in published maps and institutional affiliations.

Copyright: (C) 2021 by the authors. Licensee MDPI, Basel, Switzerland. This article is an open access article distributed under the terms and conditions of the Creative Commons Attribution (CC BY) license (https:// creativecommons.org/licenses/by/ $4.0 /)$.

\begin{abstract}
The European Union created a European Green Deal Program (EGDP). This program aims at a sustainable economy through the transformation of the challenges related to climate and the environment. The main goal of EGDP is climate neutrality by 2050 . The increase of alternative biomass residues utilization from various food processing industries and cooperation in the energy and waste management sector is required to meet these expectations. Nut shells are one of the lesser-known, yet promising, materials that can be used as an alternative fuel or a pre-treated product to further applications. However, from a thermal conversion point of view, it is important to know the energy properties and kinetic parameters of the considered biowaste. In this study, the energy and kinetic parameters of walnut, hazelnut, peanut, and pistachio shells were investigated. The results showed that raw nut shells are characterized by useful properties such as higher heating value (HHV) at $17.8-19.7 \mathrm{MJ} \cdot \mathrm{kg}^{-1}$ and moisture content of $4.32-9.56 \%$. After the thermal treatment of nut shells (torrefaction, pyrolysis), the HHV significantly increased up to ca. $30 \mathrm{MJ} \cdot \mathrm{kg}^{-1}$. The thermogravimetric analysis (TGA) applying three different heating rates $\left(\beta ; 5,10\right.$, and $\left.20^{\circ} \mathrm{C} \cdot \mathrm{min}^{-1}\right)$ was performed. The kinetic parameters were determined using the isothermal model-fitting method developed by Coats-Redfern. The activation energy $\left(E_{a}\right)$ estimated for $\beta=5^{\circ} \mathrm{C} \cdot \mathrm{min}^{-1}$, was, e.g., $60.3 \mathrm{~kJ} \cdot \mathrm{mol}^{-1} \cdot \mathrm{K}^{-1}$ for walnut, $59.3 \mathrm{~kJ} \cdot \mathrm{mol}^{-1} \cdot \mathrm{K}^{-1}$ for hazelnut, $53.4 \mathrm{~kJ} \cdot \mathrm{mol}^{-1} \cdot \mathrm{K}^{-1}$ for peanut, and $103.8 \mathrm{~kJ} \cdot \mathrm{mol}^{-1} \cdot \mathrm{K}^{-1}$ for pistachio, respectively. Moreover, the increase in the $E_{a}$ of nut shells was observed with increasing the $\beta$. In addition, significant differences in the kinetic parameters of the biomass residues from the same waste group were observed. Thus, characterization of specific nut shell residues is recommended for improved modeling of thermal processes and designing of bioreactors for thermal waste treatment.
\end{abstract}

Keywords: biomass residues; food processing; food waste; waste management; thermal treatment; pyrolysis; activation energy; kinetic parameters; torrefaction; kinetic modeling; Coats-Redfern method; isoconversional thermal degradation; biorenewables

\section{Introduction}

The European Union (EU) and all the associated countries, including Poland, belong to the European Green Deal Program. The Green Deal assumes a common plan for the sustainable economy through the transformation of the challenges related to climate and the environment [1]. The EU aims to achieve climate neutrality by 2050. The goal is achievable via transitioning to cleaner and renewable energy sources. Renewable energy creates possibilities to be implemented in several sectors: manufacturing, cement, consumer goods production processes, transport, food, or agriculture [1]. Climate neutrality can be promoted via shorter-term EU 2030 goals such as reducing greenhouse gases (GHG) by $40 \%$, increasing the share of the renewable energy sources to $32 \%$, and increasing energy efficiency by $32.5 \%[2,3]$.

Biomass can play an important role in an attempt to achieve climate neutrality by 2050 . The biomass is responsible for energy biodiversity, carbon capture and storage (CCS), air 
quality, and GHG emissions [4]. It is still possible to increase the biomass role and share in climate neutrality achievement plans, especially in energy generation, agriculture, and food processing. We have been promoting biomass conversion and utilization opportunities, especially focused on less popular, variable, random, and often scattered materials such as organic waste from food processing. Furthermore, processing the waste from this sector is in line with current trends covering sustainable waste management and effective reuse of biomass residues. Such an approach allows for the reduction of the waste storage amounts and, thus, negative environmental footprint.

Biomass has a significant potential, which can be an alternative source for reuse in other processes. The data analysis performed by the European Commission (EC) within the EU showed that $\sim 88$ million tons of food waste are generated annually with associated costs estimated at 143 billion euros [5]. Waste generated during the food processing amounted to $20 \%$ (16.9 million tons) [6]. Similarly, a significant amount of food waste (mostly fruits and vegetables) was also observed in Asia and the U.S. [7]. The whole logistic chain of the fruit and vegetable sector, including processing, packing, distribution, and consumption, generates approximately 1.81, 32.0, and 15.0 million tons of waste in India, China, and the U.S., respectively [7].

According to the data presented by The Food and Agriculture Organization of the United Nations [8], nuts crops cover close to 1,200,000 ha in Europe (Table 1), producing ca. 1.2 Gt of nuts per year. Assuming that an average amount of wastes from nuts is $40 \%$ [9], over 500 kt of nut shells are generated. In Poland, taking into account the domestic production of hazelnut and walnut, over $15 \mathrm{kt}$ of nuts are produced, which corresponds to approximately $6 \mathrm{kt}$ of waste. It should be marked that in practice, the total amount of wastes from nuts is higher due to the nuts import and their processing in Poland. However, this biomass residue requires proper management to use its energy potential.

Table 1. Harvested area, fruit production, and nut waste generation in Europe and Poland [8].

\begin{tabular}{ccccccc}
\hline \multirow{2}{*}{ Crops } & \multicolumn{3}{c}{ Europe } & \multicolumn{3}{c}{ Poland } \\
\cline { 2 - 7 } & $\begin{array}{c}\text { Area, } \\
\text { ha }\end{array}$ & $\begin{array}{c}\text { Production, } \\
\mathbf{M g}\end{array}$ & $\begin{array}{c}\text { Waste, } \\
\mathbf{M g}\end{array}$ & $\begin{array}{c}\text { Area, } \\
\text { ha }\end{array}$ & $\begin{array}{c}\text { Production, } \\
\mathbf{M g}\end{array}$ & $\begin{array}{c}\text { Waste, } \\
\mathbf{M g}\end{array}$ \\
\hline $\begin{array}{c}\text { Fruit } \\
\text { total) }\end{array}$ & $7,481,716$ & $87,574,401$ & - & 379,056 & $5,140,130$ & - \\
Nuts & & & & & & \\
(total) & $1,191,510$ & $1,254,799$ & 501,920 & 6322 & 15,119 & 6048 \\
Hazelnut & 117,057 & 173,946 & 69,578 & 3716 & 6642 & 2657 \\
$\begin{array}{c}\text { Pistachio } \\
\text { Walnut }\end{array}$ & 37,754 & 20,699 & 8280 & - & - & - \\
\hline
\end{tabular}

Thermal processing via torrefaction and pyrolysis significantly increases and expands its application potential (energy generation, fertilizers, and bio-polymers production), which makes the circular economy goals more attractive (Figure 1).

The impact of thermal processing on the physicochemical properties of many popular types of biomass is known. The studies about biomass torrefaction and pyrolysis [10-15] showed that the higher temperature of the biomass processing improves its thermal properties. The biochar is characterized by higher heating value, lower moisture content, lower volatile matter content, and improved hydrophobicity. The torrefied biomass is initially sterile and much more resistant to decay, and therefore it can be stored for a longer time [11]. As it is known, the first stage in thermal processes is dehydration. The raw nut shells have much less moisture content (MC) in comparison to the other organic waste biomass. The MC in nuts depends on their type and amounts to $20 \%$ for walnut [16], $6 \%$ for peanuts [17], $7 \%$ for pistachio [18], and 28\% for hazelnut [19]. Thanks to the lower MC, nut shells require less heat for dehydration and are interesting materials for thermal processing. 


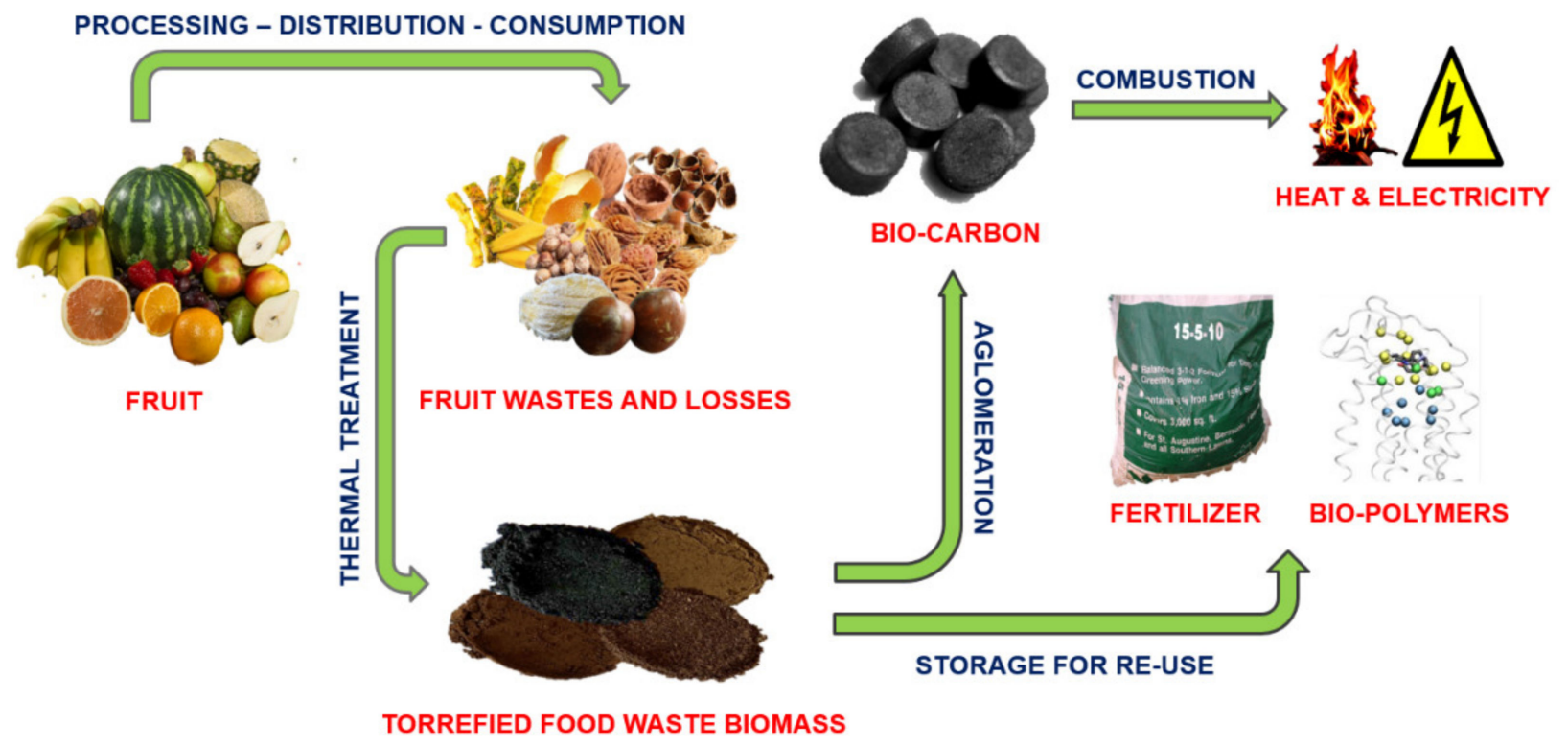

Figure 1. Proposed treatment and further development direction of the fruit and nuts processing waste biomass.

Kinetics helps in understanding how to control and optimize the process of biomass thermal treatment. Description of the kinetic process includes such kinetic parameters as activation energy $\left(E_{a}\right)$, pre-exponential factor $(\mathrm{A})$, the reaction rate constant $(\mathrm{k})$, and reaction order (n). Improved knowledge of these parameters enables modeling the thermal process, designing and optimizing the bioreactor for biomass torrefaction and pyrolysis. The kinetic process presents the biomass material response to the temperature change during the treatment process. It identifies the range of temperatures in which specific reactions take place in the material.

There are many kinetic models in use. Some of the better-known kinetics modeling methods include Freidman, Kissinger-Ozawa, Kissinger-Akahira-Sunose (KAS), FlynnWall-Ozawa (FWO), and the Coats-Redfern Method [20]. Due to the different content of the lignin, cellulose, and hemicellulose in biomass, there are differences between the thermal decomposition of these materials. The easiest fiber to depolymerize is hemicellulose due to its low molecular weight. Next is cellulose, and the hardest fiber to decompose is lignin [21-23].

The thermogravimetric (TGA)-based studies have shown that hemicellulose decomposes at the lowest temperature $\left(200{ }^{\circ} \mathrm{C}\right.$ to $\left.350{ }^{\circ} \mathrm{C}\right)$, then the cellulose $\left(300{ }^{\circ} \mathrm{C}\right.$ to $\left.400{ }^{\circ} \mathrm{C}\right)$, and the lignin decompose at the wider range of temperatures $\left(150{ }^{\circ} \mathrm{C}\right.$ to as high as $900{ }^{\circ} \mathrm{C}$ ) [24-26]. Similar thermal decomposition characterization of the lignin, cellulose, and hemicellulose was observed by Zhou [27]. These studies were carried out based on the agricultural biomass samples like sugar cane bagasse, rice straw, rice husk, cotton stalk, and corncob; wooden biomass like pine sawdust; and the pure chemical hemicellulose, cellulose, and lignin. The biomass multi-reaction decomposition was confirmed by Lu et al. [28]. The TGA showed that biomass conversion was characterized by a two-stage reaction and different $E_{a}$. For the first stage decomposition, $E_{a}$ was from 75 to $85 \mathrm{~kJ} \cdot \mathrm{mol}^{-1}$, and for the second stage was $3-4 \mathrm{~kJ} \cdot \mathrm{mol}^{-1}$ [28]. Types of biomass influence the $E_{a}$ that can range from $66 \mathrm{~kJ} \cdot \mathrm{mol}^{-1}$ (corn stalk) to $227 \mathrm{~kJ} \cdot \mathrm{mol}^{-1}$ (filter paper). The wooden chips and the wheat straw have $E_{a}$ of $85 \mathrm{~kJ} \cdot \mathrm{mol}^{-1}$ and $70 \mathrm{~kJ} \cdot \mathrm{mol}^{-1}$, respectively [29]. The relations between the type of biomass and decomposition kinetics were also observed in other studies; the $E_{a}$ was from 150 to $550 \mathrm{~kJ} \cdot \mathrm{mol}^{-1}$ depending on the type of biomass [30,31]. It should be noted that the heating rate $(\beta)$ also has an important impact on the kinetics. As a result, the different $E_{a}$ was noted, according to the various heating rates. An increasing $\beta$ resulted in higher $E_{a}$ for the polyethylene materials [32]. 
To date, the nut shells are used as an alternative fuel, mainly in the untreated form. The common use is, pelletizing the nut shells, e.g., from walnut, pistachio, or hazelnut $[33,34]$. There are a few studies describing the basic energy properties of the nut shells. Investigating the Brazil nut shells the authors have shown that the HHV amounted to $20.4 \mathrm{MJ} \cdot \mathrm{kg}^{-1}$, ash content varied from 1.7 to $3.2 \%$, and volatiles were $71.6 \%$ [35,36]. In other studies, the walnuts, hazelnuts, and pistachio shells were investigated and characterized by $\mathrm{HHV}=20.2 ; 21.6 ; 17.4 \mathrm{MJ} \cdot \mathrm{kg}^{-1}$, ash content $(\mathrm{AC})=1.4 ; 2.8 ; 0.41 \%$, and volatile matter content $(\mathrm{VMC})=59.3,70.3,77.5 \%$, respectively $[37,38]$. Nut shells were also investigated during the pyrolysis and torrefaction process. The effect of thermal processing on the basic properties of the nut shells such as walnut, hazelnut, or pistachio was confirmed. Torrefied nut shells were characterized by higher HHV, lower VMC, and higher fixed carbon content with the increasing temperature of the process $[37,39,40]$. Torrefied hazelnut shells were characterized by HHV of $26.7 \mathrm{MJ} \cdot \mathrm{kg}^{-1}$ (at $300{ }^{\circ} \mathrm{C}$ ) [40]. Walnut, hazelnut, almond, and sunflower shells pyrolyzed at $500{ }^{\circ} \mathrm{C}$ were characterized by $\mathrm{HHV}$ of $30 \mathrm{MJ} \cdot \mathrm{kg}^{-1}$ [37]. Such values of $\mathrm{HHV}$ are very competitive in comparison to bituminous coal, which is still a very common fossil fuel used for energy purposes.

In addition to the energetic use (heat and power production through combustion or co-combustion), the nut shells are also valuable for the acquisition of bio-components. Due to their lignocellulosic structure, they are used for pure lignin and cellulose production. Especially the pistachio shells are processed for the cellulose nanocrystals acquisition [41]. The cellulose nanocrystals are also produced from other nut shells such as walnut [42]. There are also studies investigating the kinetics of walnut, hazelnut, peanut, and pistachio shells thermal decomposition. However, many of these studies use different kinetic models and reactions mechanism.

Therefore, the aim of this work was to characterize the thermal decomposition and to determine the kinetic parameters of the pyrolysis process of the wastes from nuts processing applying the Coats-Redfern method. Shells from different types of nuts (walnut, hazelnut, peanut, and pistachio) were selected. The objectives of this research were: (i) carrying out detailed thermogravimetric analysis (TGA) of the nut shells, (ii) determination of the characteristic points in the nut shells thermal decomposition process, (iii) finding the temperature range of the hemicellulose, cellulose, and lignin decomposition in the investigated nut shells, (iv) estimation of the basic kinetic parameters of the nut shells thermal decomposition, (v) characterization of the nut shells conversion rates as a function of the process temperature.

\section{Materials and Methods}

\subsection{Characteristic of the Materials Used in the Research}

Four types of nuts biomass wastes were investigated (Figure 2): (a) walnut shells (WS), (b) hazelnut shells (HS), (c) peanut shells (PES), and (d) pistachio shells (PIS).

The research materials were initially dried in the drying chamber KBC-65 W (WAMED, Warszawa, Poland) (Figure 3a) for $24 \mathrm{~h}$ at $105^{\circ} \mathrm{C}$. For the TGA, the waste biomass from nuts (shells) was ground in the mill (LMN 400, TESTCHEM, Pszów, Poland) (Figure 3b) with a sieve size of $1 \mathrm{~mm}$.

In order to characterize the fruit waste biomass - nut shells, the proximate and elemental analyses were carried out. The proximate analysis included determination of ash MC, AC, VMC, higher and lower heating value (HHV and LHV), and calculation of fixed carbon content (FFC) based on the basic energy properties. The proximate analysis was carried out in accordance with the standards listed in Table 2 . Three repetitions were performed. 

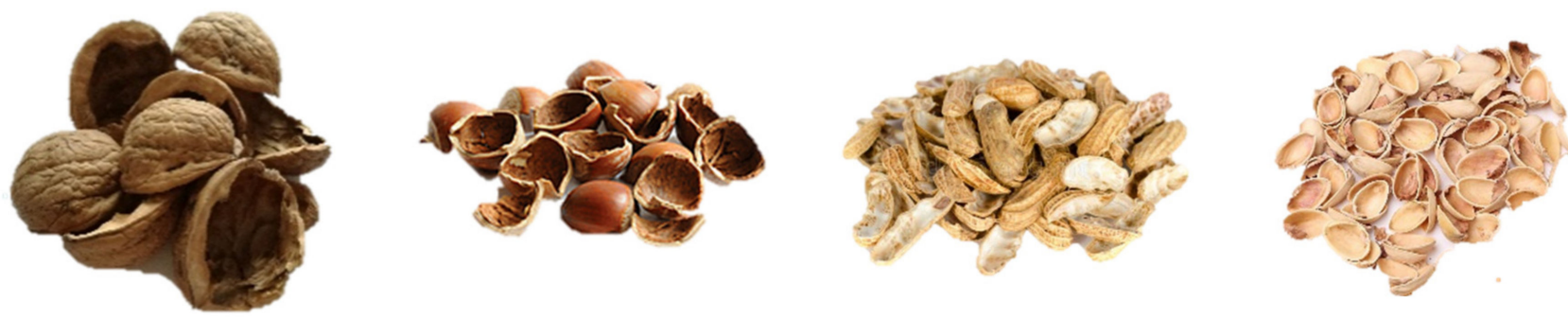

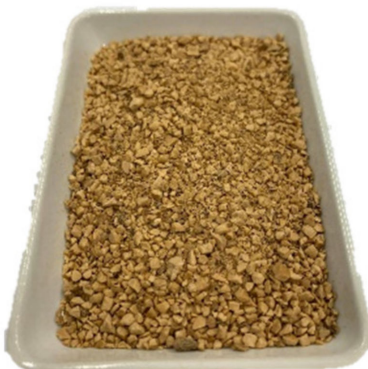

(a)

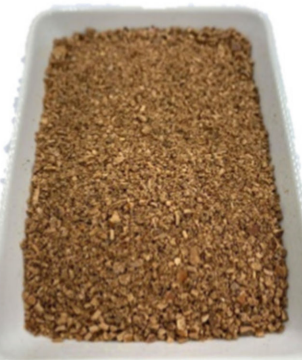

(b)

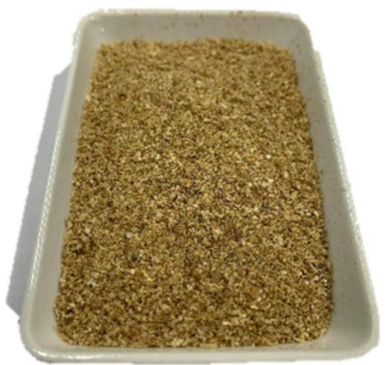

(c)

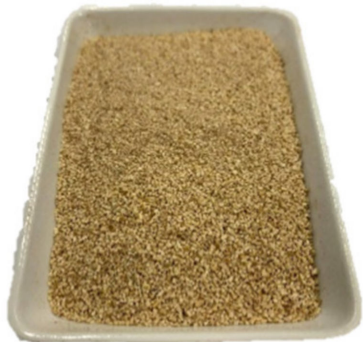

(d)

Figure 2. Waste biomass (nut shells) used in experiments: walnut (a), hazelnut (b), peanut (c), and pistachio (d).

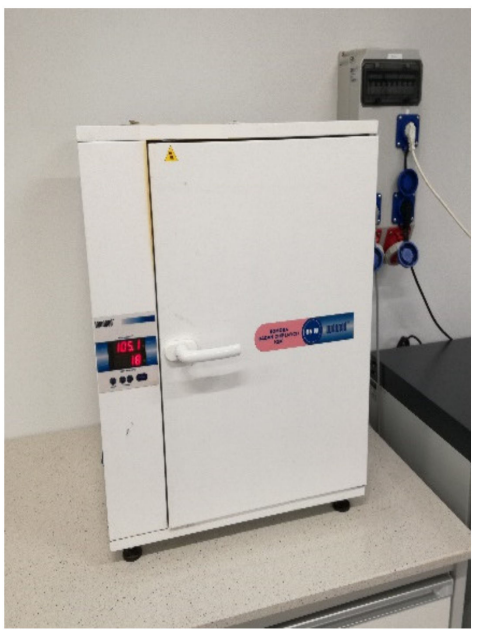

(a)

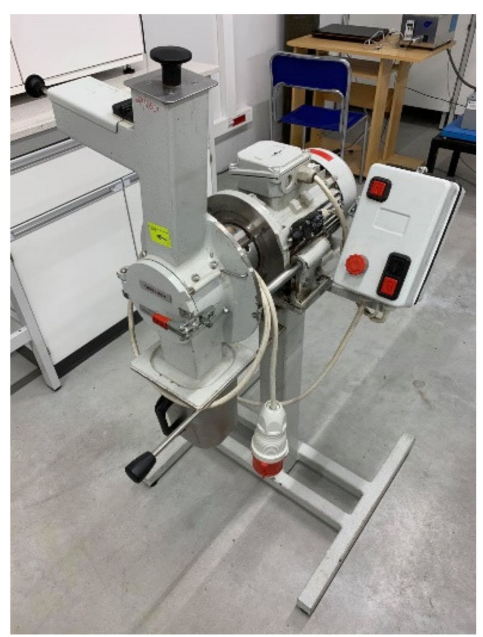

(b)

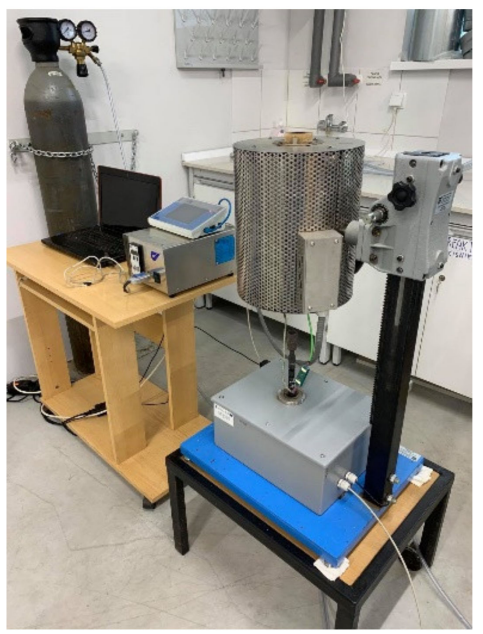

(c)

Figure 3. Laboratory devices: drying chamber KBC-65 W (a); biomass mill LMN 400 (b); thermogravimetric analyzerPyrolysis Biomass Gasifier No. 11/14/3 (c).

Table 2. Analysis standards and methods of proximate analysis.

\begin{tabular}{cc}
\hline Analysis & Standard \\
\hline Moisture content (MC) & PN EN ISO 18134-2:2017-03E \\
Ash content (AC) & PN EN ISO 18122:2015 \\
Volatile matter content (VMC) & PN EN ISO 18123:2016-01 \\
Higher heating value (HHV) & PN EN ISO 18125:2017-07 \\
Lower heating value (LHV) & Calculation based on the HHV and MC [10] \\
Fixed carbon content (FCC) & ASTM D-3172-73 \\
\hline
\end{tabular}

The elemental analysis of the used waste biomass was carried out in the organic elemental analyzer FLASH 2000 CHNO/S (THERMO SCIENTIFIC, Waltham, MA, USA). 


\subsection{Thermogravimetric Analysis}

The prepared material ( $3 \mathrm{~g}$ per sample) was inserted into the thermogravimetric analyzer Pyrolytic Biomass Gasifier No. 11/14/3 (ROTAMETR, Gliwice, Poland) (Figure 3c). The crucible with the research material introduced into the reactor is integrated with the laboratory scale (AS 220.R2, RADWAG, Radom, Poland) to control the change of its mass as a function of time and process temperature. Inert gas $\left(\mathrm{CO}_{2}\right.$ from the compressed gas cylinder at $6 \mathrm{dm}^{3} \cdot \mathrm{h}^{-1}$ ) was introduced to the chamber to maintain pyrolysis conditions. The TGA was carried out from $30^{\circ} \mathrm{C}$ to $900^{\circ} \mathrm{C}$. Three heating rates $\left(\beta ; 5,10,20^{\circ} \mathrm{C} \cdot \mathrm{min}^{-1}\right)$ were applied at $n=3$ repetitions.

\subsection{Kinetic Modelling}

The kinetics of the biomass samples were studied considering a constant $\beta$. The pyrolysis of the biomass can be generally described as [20,43]:

\begin{tabular}{llll}
\hline Raw biomass & Biochar & + & Pyrolysis gases \\
(solid fraction) & (solid fraction) & (volatile fraction) \\
\hline
\end{tabular}

The recommendations of kinetic modeling of the biomass thermal decomposition were well described and published by ICTAC Kinetics Committee and other researchers [43-45]. Decomposition of the solid biomass under the isothermal conditions can be expressed as:

$$
\frac{d \alpha}{d t}=k f(\alpha)
$$

where: $k$ is a process rate constant (-), $\alpha$ is a conversion rate of the process (-).

The $\alpha$ of the solid material during the pyrolysis is described as:

$$
\alpha=\frac{M_{i}-M_{t}}{M_{i}-M_{f}}
$$

where: $M_{i}$ is an initial mass of the sample $(\mathrm{mg}), M_{t}$ is a mass of the sample in the given time $(\mathrm{mg})$, and $M_{f}$ is a final mass of the sample $(\mathrm{mg})$. The reaction rate constant and relative mass loss can be described by the Arrhenius law:

$$
k=A \cdot e^{\frac{-E_{a}}{R T}}
$$

where: $k$ is a reaction constant $(-), A$ is the pre-exponential factor $\left(\mathrm{s}^{-1}\right), E_{a}$ is activation energy $\left(\mathrm{kJ} \cdot \mathrm{kmol}^{-1}\right), R$ is a universal gas constant $\left(R=8.3145 \mathrm{~kJ} \cdot \mathrm{kmol}^{-1} \cdot \mathrm{K}^{-1}\right)$, and $T$ is the temperature (K). Merging Equation (3) with Equation (1) yields:

$$
\frac{d \alpha}{d t}=A \cdot e^{\frac{-E_{a}}{R T}} \cdot f(\alpha)
$$

The function of the conversion level $f(\alpha)$ can be described by many reaction models (Table 3).

In this study, three different $\beta s$ were applied, which are also a function of time. For the non-isothermal conditions, the linear $\beta$ can be described as:

$$
\beta=\frac{d T}{d t}
$$

where: $d T$ is a temperature change $(K), \mathrm{dt}$ is a time change $(h)$.

The final formula for the thermal decomposition of the biomass is determined by inserting Equation (5) to Equation (4):

$$
\frac{d \alpha}{d t}=\beta \frac{d \alpha}{d T}=A \cdot e^{\frac{-E_{a}}{R T}} \cdot f(\alpha) \text { or }
$$




$$
\frac{d \alpha}{d T}=\frac{A}{\beta} \cdot e^{\frac{-E_{a}}{R T}} \cdot f(\alpha)
$$

Equation (8) below is the general formula of the thermal decomposition of the solid biomass material. It is integrated and recombined with Equation (7), where $g(\alpha)$ is a known integrated kinetic reaction model (Table 3):

$$
g(\alpha)=\int_{0}^{\alpha} \frac{d \alpha}{f(\alpha)}=\frac{A}{\beta} \int_{0}^{T} \exp \left(\frac{-E a}{R T}\right) d T
$$

Table 3. Kinetic reactions models $f(\alpha)$ and $g(\alpha)[43,46,47]$.

\begin{tabular}{clcc}
\hline Reaction Model & Code & $f(\alpha)$ & $g(\alpha)$ \\
\hline Avrami-Erofeev & A2 & $2(1-\alpha)[-\ln (1-\alpha)]^{1 / 2}$ & {$[-\ln (1-\alpha)]^{1 / 2}$} \\
Avrami-Erofeev & A3 & $3(1-\alpha)[-\ln (1-\alpha)]^{2 / 3}$ & {$[-\ln (1-\alpha)]^{1 / 3}$} \\
Avrami-Erofeev & A4 & $4(1-\alpha)[-\ln (1-\alpha)]^{3 / 4}$ & {$[-\ln (1-\alpha)]^{1 / 4}$} \\
1-D diffusion & D1 & $1 / 2 \alpha^{-1}$ & $\alpha^{2}$ \\
2-D diffusion & D2 & {$[-\ln (1-\alpha)]^{-1}$} & $(1-\alpha) \ln (1-\alpha)+\alpha$ \\
3-D diffusion & D3 & $3 / 2(1-\alpha)^{2 / 3}\left[1-(1-\alpha)^{1 / 3}\right]^{-1}$ & {$\left[1-(1-\alpha)^{1 / 3}\right]^{2}$} \\
Mampel (first-order) & F1 & $1-\alpha$ & $-\ln (1-\alpha)$ \\
Power law & P2 & $4 \alpha^{3 / 4}$ & $\alpha^{1 / 2}$ \\
Power law & P3 & $3 \alpha^{2 / 3}$ & $\alpha^{1 / 3}$ \\
Power law & P4 & $2 \alpha^{1 / 2}$ & $\alpha^{1 / 4}$ \\
Power law & P2/3 & $2 / 3 \alpha^{-1 / 2}$ & $\alpha^{3 / 2}$ \\
Contracting cylinder & R2 & $2(1-\alpha)^{1 / 2}$ & $1-(1-\alpha)^{1 / 2}$ \\
Contracting sphere & R3 & $3(1-\alpha)^{2 / 3}$ & $1-(1-\alpha)^{1 / 3}$ \\
n-order reaction & - & $(1-\alpha)^{\mathrm{n}}$ & $1-(1-\alpha)^{1-\mathrm{n} / 1-\mathrm{n}}$ \\
\hline
\end{tabular}

\subsection{Model-Fitting Method: Coats-Redfern Method}

The biomass decompositions kinetic model was based on the Coats-Redfern method [29,43,48-50]. The Coats-Redfern method uses the Taylor series applied to the experimental data and limits the numbers of terms in the series. The Taylor series approach can be described as:

$$
\begin{gathered}
g(x)=\frac{A E}{\beta R} p(x)=\frac{A E}{\beta R}\left[\frac{e^{-x}}{x^{2}}\left(1-\frac{2 !}{x}+\frac{3 !}{x^{2}}+\frac{4 !}{x^{3}}+\ldots\right)\right]=\frac{A E}{\beta R}\left[\frac{e^{-x}}{x^{2}}\left(1-\frac{2}{x}\right)\right]= \\
=\frac{A E}{\beta R}\left[\frac{e^{-E / R T}}{\left(\frac{E}{R T}\right)^{2}}\left(1-\frac{2}{\left(\frac{E}{R T}\right)}\right)\right]=\frac{A R T^{2}}{\beta E}\left(1-\frac{2 R T}{R T E}\right) e^{\left(\frac{-E}{R T}\right)}
\end{gathered}
$$

Applying the n-order reaction function from Table 3 to Equation (8) results in:

$$
g(\alpha)=\int_{0}^{\alpha} \frac{d \alpha}{(1-\alpha)^{n}}=\frac{A}{\beta} \int_{0}^{T} \exp \left(\frac{-E}{R T}\right) d T
$$

According to the order of reaction, the expression of Equation (10) is:

$$
\begin{gathered}
\text { for } n=1 \quad g(x)=-\ln (1-\alpha) \\
\text { for } n \neq 1 g(x)=\frac{1}{1-n}\left[(1-\alpha)^{1-n}-1\right]
\end{gathered}
$$

Applying Equations (11) and (12) into Equation (9), the final formulas are:

$$
\begin{gathered}
\text { For } n=1 \ln \left(-\frac{\ln (1-\alpha)}{T^{2}}\right)=\ln \left[\frac{A R}{\beta E_{a}}\right]-\frac{E_{a}}{R T} \\
\text { For } n \neq 1 \ln \left(\frac{1-(1-\alpha)^{1-n}}{T^{2}(1-n)}\right)=\ln \left[\frac{A R}{\beta E_{a}}\right]-\frac{E_{a}}{R T}
\end{gathered}
$$


The $\frac{2 R T}{R T E}$ was dropped from Equations (13) and (14) because its value is $<1$. Then, by plotting the left side of Equations (13) and (14) versus 1/T, the straight line was fitted using linear regression. The $E_{a}$ was estimated as a slope of the straight line based on the best fitted linear regression and the coefficient of determination $\left(\mathrm{R}^{2}\right)$. The $A$ was calculated based on the intercept of the straight line.

$$
\text { intercept }=\ln \frac{A R}{\beta \cdot E_{a}}
$$

where: $A$ is the pre-exponential factor $\left(\mathrm{s}^{-1}\right), R$ is a universal gas constant $(R=8.3145$ $\left.\mathrm{kJ} \cdot \mathrm{kmol}^{-1} \cdot \mathrm{K}^{-1}\right), \beta$ is the heating rate $\left({ }^{\circ} \mathrm{C} \cdot \mathrm{min}^{-1}\right), E_{a}$ is activation energy $\left(\mathrm{kJ} \cdot \mathrm{kmol}^{-1}\right)$.

\section{Results and Discussion}

\subsection{Proximate and Ultimate Analysis}

The obtained results (Table 4) indicate that the raw nut shells have potentially useful energy potential. Their average HHV was approximately $19.4 \mathrm{MJ} \cdot \mathrm{kg}^{-1}$ (excluding the PIS, for which $\mathrm{HHV}=17.8 \mathrm{MJ} \cdot \mathrm{kg}^{-1}$. The MC was between $4.3 \%$ (for WS) and $9.6 \%$ (for HS). Whereas the AC ranged from $1.0 \%$ for HS to $3.1 \%$ for PIS. The highest content of the FC was observed for the WS (13.14\%), the lowest for PIS (8.26\%).

Table 4. Proximate and ultimate analysis of nut shells.

\begin{tabular}{|c|c|c|c|c|c|c|}
\hline & Parameter & & WS & HS & PES & PIS \\
\hline \multirow{6}{*}{$\begin{array}{l}\text { Proximate } \\
\text { analysis }\end{array}$} & $\mathrm{MC}$ & $\%$ & $4.32 \pm 0.11$ & $9.56 \pm 0.00$ & $6.32 \pm 0.01$ & $7.05 \pm 0.01$ \\
\hline & $\mathrm{HHV}$ & \multirow{2}{*}{$\mathrm{MJ} \cdot \mathrm{kg}^{-1}$} & $19,604 \pm 330$ & $18,887 \pm 80$ & $19,692 \pm 57$ & $17,780 \pm 57$ \\
\hline & LHV & & $18,731 \pm 316$ & $17,078 \pm 72$ & $18,446 \pm 53$ & $16,528 \pm 53$ \\
\hline & $\mathrm{AC}$ & \multirow{3}{*}{$\%$} & $1.10 \pm 0.20$ & $1.00 \pm 0.20$ & $2.20 \pm 0.40$ & $3.10 \pm 0.60$ \\
\hline & VMC & & $81.44 \pm 1.26$ & $78.04 \pm 0.05$ & $78.84 \pm 0.40$ & $81.24 \pm 0.26$ \\
\hline & $\mathrm{FC}$ & & $13.14 \pm 0.57$ & $11.39 \pm 0.09$ & $12.57 \pm 0.33$ & $8.26 \pm 0.25$ \\
\hline \multirow{5}{*}{$\begin{array}{l}\text { Ultimate } \\
\text { analysis }\end{array}$} & $\mathrm{C}$ & \multirow{5}{*}{$\%$} & $48 \pm 10$ & $49 \pm 10$ & $49 \pm 10$ & $44 \pm 9$ \\
\hline & $\mathrm{H}$ & & $8.0 \pm 1.6$ & $7.8 \pm 1.6$ & $7.9 \pm 1.6$ & $7.9 \pm 1.6$ \\
\hline & $\mathrm{N}$ & & $0.31 \pm 0.06$ & $0.43 \pm 0.09$ & $1.2 \pm 0.2$ & $0.2 \pm 0.04$ \\
\hline & $\mathrm{O}$ & & $42.6 \pm 8.5$ & $41.8 \pm 8.4$ & $39.6 \pm 7.9$ & $44.8 \pm 9.0$ \\
\hline & $S$ & & $0.014 \pm 0.003$ & $0.019 \pm 0.004$ & $0.083 \pm 0.017$ & $0.014 \pm 0.003$ \\
\hline
\end{tabular}

The ultimate analysis showed that the elemental characteristics of nut shells are similar. Their carbon content was between $44 \%$ (PIS) and $49 \%$ (HS, PES). Hydrogen, N, and O content was from 7.8 to $8.0 \%, 0.2-1.2 \%$, and $39.6-44.8 \%$, respectively. The $\mathrm{S}$ content was below $0.1 \%$.

It can be concluded that nut shells have a remarkable energy potential. The investigated WS, HS, PES, and PIS meet fuel properties limitations of the non-woody biomass pellets (A standard). In accordance with the ISO 17225-6: 2014 (E), the non-woody pellets (A standard) can have $\mathrm{HHV} \geq 14.5 \mathrm{MJ} \cdot \mathrm{kg}^{-1}, \mathrm{AC} \leq 6 \%$, and $\mathrm{MC} \leq 12 \%$. All tested materials meet this HHV, AC, and MC limitations. However, the energy parameters for WS and HS are superior to PES and PIS. Their properties, especially HHV, AC, and MC, meet the limitations for the woody biomass-ISO 17225-2: 2014 (E). WS and HS meet industrial use standard I1, which limits $\mathrm{HHV} \geq 16.5 \mathrm{MJ} \cdot \mathrm{kg}^{-1}, \mathrm{AC} \leq 1 \%$, and $\mathrm{MC} \leq 10 \%$. Additionally, WS and HS meet standard A2 for the small scale use (HHV $\geq 16.5 \mathrm{MJ} \cdot \mathrm{kg}^{-1}, \mathrm{AC} \leq 1.2 \%$, and $\mathrm{MC} \leq 10 \%)$. 


\subsection{Thermogravimetric Analysis (TGA) and Derivative Thermogravimetric Analysis (DTG)}

Analyzing the data obtained for nut shells (WS, HS, PES, and PIS), it can be seen that the $\beta$ in the process of thermal treatment of waste biomass affects the values of kinetic parameters of the process $\left(E_{a}\right.$, pre-exponential factor, and $k$ ). The three stages were observed for the tested materials (Figure 4) as in other studies [51]. Analyzing the TGA curves for nut shells (Figure 4), the shift in the initiation of the decomposition process for all materials was observed. This thermal decomposition shift between the heating rates was approximately $50-70{ }^{\circ} \mathrm{C}$. It is associated with the thermal capacity of the material, which influences its internal heat transfer. The faster heating rate causes that the biomass is exposed to a given temperature effect for a shorter period of time. Thus, the material requires a higher temperature to start decomposing.

The first characteristic stage of the process for $\beta=5^{\circ} \mathrm{C} \cdot \mathrm{min}^{-1}$ starts at approximately $140{ }^{\circ} \mathrm{C}$ and ends at approximately $264^{\circ} \mathrm{C}$ for all the investigated nut shells. At $360^{\circ} \mathrm{C}$, materials intensively released volatiles, which was the second stage of the thermal decomposition. The temperature of the start and end of the first and second stage was different for the three $\beta$ s.

The main process of the pyrolysis started between the $500{ }^{\circ} \mathrm{C}$ and $600{ }^{\circ} \mathrm{C}$. Interestingly, at approximately $600{ }^{\circ} \mathrm{C}$ WS, HS, and PIS reached the same weight loss $(60-70 \%)$ of the initial mass. The obtained TGA curve was characteristic for lignocellulosic biomass decomposition. Similar results and TGA waveform were also noted for other waste and biomass [23,52].

The TGA is also based on the derivative thermogravimetric analysis (DTG), where the amount of mass loss was determined for each material. The main characteristic feature is an increased amount of weight loss. It can be observed that nut shells were characterized by a higher rate of weight loss at $\beta=20^{\circ} \mathrm{C} \cdot \mathrm{min}^{-1}$ than at $\beta=5^{\circ} \mathrm{C} \cdot \mathrm{min}^{-1}$. For the WS and HS, the maximum weight loss was approximately 0.76 and $0.56 \% \cdot{ }^{\circ} \mathrm{C}^{-1}$ for $\beta=2{ }^{\circ} \mathrm{C} \cdot \mathrm{min}^{-1}$, 0.51 and $0.49 \% \cdot{ }^{\circ} \mathrm{C}^{-1}$ for $\beta=10{ }^{\circ} \mathrm{C} \cdot \mathrm{min}^{-1}$, and 0.54 and $0.45 \% \cdot{ }^{\circ} \mathrm{C}^{-1}$ for $\beta=5{ }^{\circ} \mathrm{C} \cdot \mathrm{min}^{-1}$, respectively. For the PES, the maximal derivative mass loss was $0.5-0.6 \% \cdot{ }^{\circ} \mathrm{C}^{-1}$ and was increasing with the $\beta$. Interestingly, for the PIS, the maximal derivative mass loss was decreasing with increasing $\beta\left(0.85 \% \cdot{ }^{\circ} \mathrm{C}^{-1}\right.$ for $\beta=5$ and $10{ }^{\circ} \mathrm{C} \cdot \mathrm{min}^{-1} ; 0.60 \% \cdot{ }^{\circ} \mathrm{C}^{-1}$ for $\left.\beta=20^{\circ} \mathrm{C} \cdot \mathrm{min}^{-1}\right)$.

\subsection{Peak Analysis during TGA}

Analyzing the peaks observed on the DTG curves of the nut shells it is possible to characterize the main thermal decomposition stages and determine their kinetic parameters. The fit peaks analyzer tool was used to find the peaks and their temperatures. The fitted peaks reflect the processes of the fibers' decompositions such as cellulose, lignin, and hemicellulose (Figures 5 and 6). For all tested materials, three main peaks (characterized by a different range of temperatures and kinetic parameters) were fitted.

The first peak was characteristic of the decomposition of the hemicellulose. This process took place at the range of temperature from 140 to $264^{\circ} \mathrm{C}\left(\beta=5^{\circ} \mathrm{C} \cdot \mathrm{min}^{-1}\right)$ for all nut shells. Depending on the $\beta$, it shifted from 196 to $322^{\circ} \mathrm{C}$ and from 252 to $449{ }^{\circ} \mathrm{C}$ for $\beta=10^{\circ} \mathrm{C} \cdot \mathrm{min}^{-1}$ and $\beta=20^{\circ} \mathrm{C} \cdot \mathrm{min}^{-1}$, respectively. 


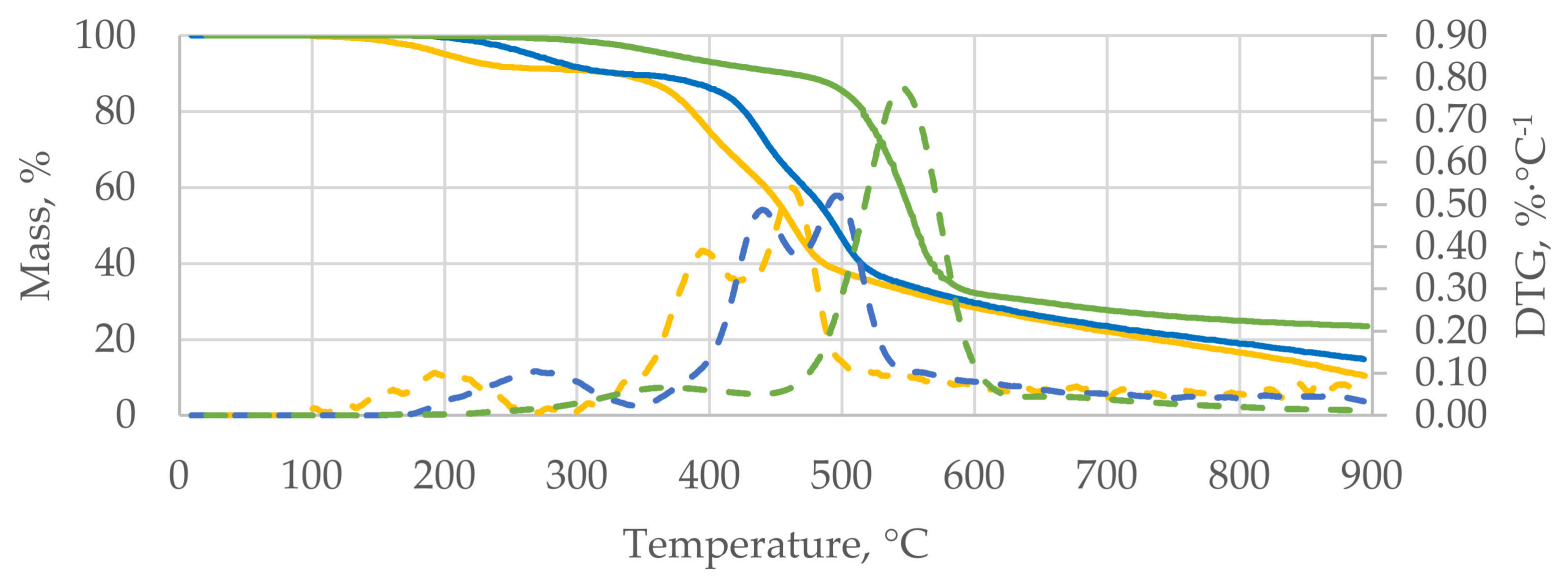

(a)

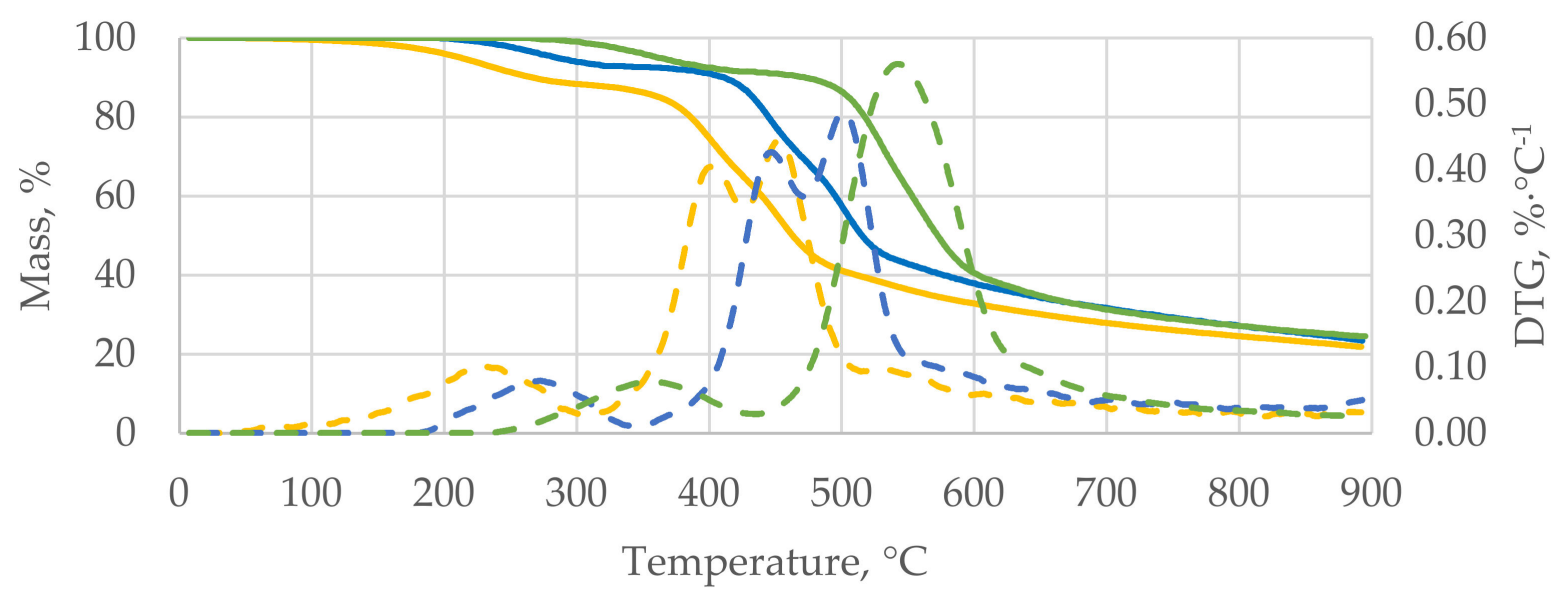

(b)

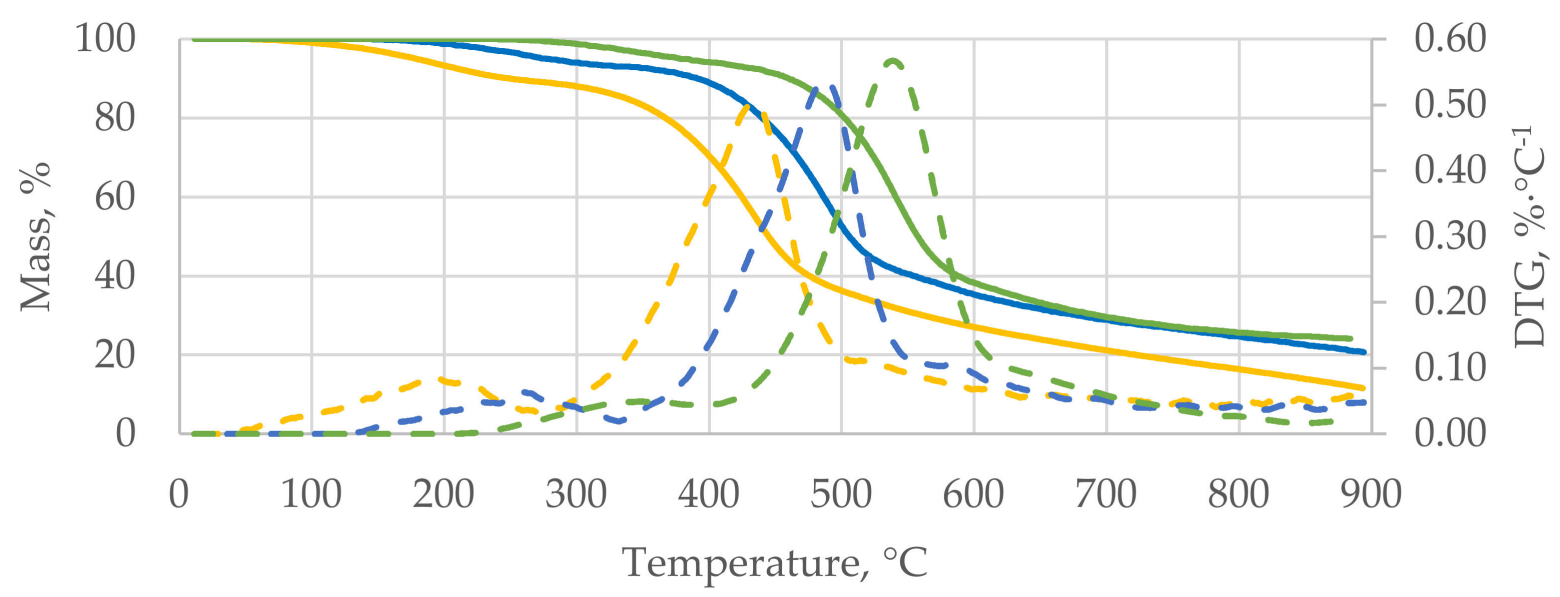

(c)

Figure 4. Cont. 


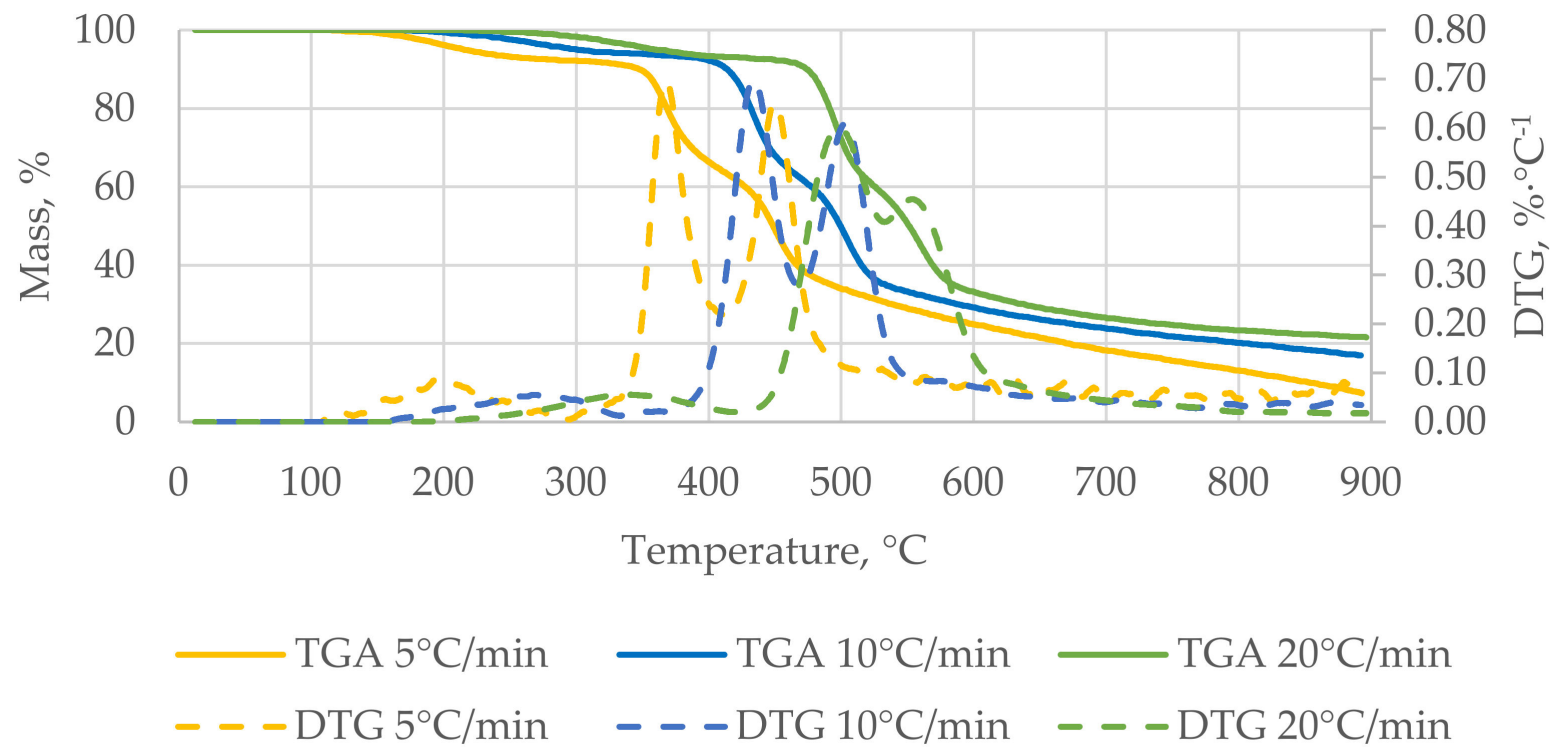

(d)

Figure 4. Thermogravimetric analysis (TGA) and derivative thermogravimetric analysis (DTG) of the walnut shells (WS) (a), hazelnut shells (HS) (b), peanut shells (PES) (c), and pistachio shells (PIS) (d).

The second reaction was typical for cellulose decomposition. This stage is significant due to its highest weight loss (DTG), by which the process was very dynamic, and the material released considerable amounts of volatile matter. The degradation of cellulose for WS and HS (at $\beta=5^{\circ} \mathrm{C} \cdot \mathrm{min}^{-1}$ ) and for PIS (at both 5 and $10^{\circ} \mathrm{C} \cdot \mathrm{min}^{-1}$ ) was represented by two reactions (confirmed by two peaks). Decomposition of the cellulose for $\beta=5^{\circ} \mathrm{C} \cdot \mathrm{min}^{-1}$ took place approximately from $353{ }^{\circ} \mathrm{C}$ to $546^{\circ} \mathrm{C}$. The second stage was detected for $\beta=10^{\circ} \mathrm{C} \cdot \min ^{-1}$ and $\beta=20^{\circ} \mathrm{C} \cdot \mathrm{min}^{-1}$, namely, from $400{ }^{\circ} \mathrm{C}$ and $472{ }^{\circ} \mathrm{C}$, respectively.

The third stage (lignin fibers decomposition) took place at a wide range of temperature from $200{ }^{\circ} \mathrm{C}$ to $800{ }^{\circ} \mathrm{C}$, in the case of PIS even from $50{ }^{\circ} \mathrm{C}$ to $900{ }^{\circ} \mathrm{C}$. This process was characterized by the slowest weight loss, often during the whole thermal treatment process. Similar results of biomass decomposition and its three main fibers were also observed in other studies [24,53-56]. Cellulose, hemicellulose, and lignin were degraded in similar ranges of temperature. Yeo [57] and Senneca [58] confirmed the order of the distribution of biomass fibers. These studies showed that hemicellulose starts to decompose at approximately $100^{\circ} \mathrm{C}$, cellulose at approximately $300^{\circ} \mathrm{C}$, and lignin at approximately $70-100{ }^{\circ} \mathrm{C}$ up to even $900{ }^{\circ} \mathrm{C}$. Decomposition of lignin caused by different drying temperatures affects other biomass conversion processes, i.e., grinding [59] and agglomeration [60].

The comprehensive analysis of the TGA peaks includes the determination of the activation energy $\left(E_{a}\right)$ and pre-exponential factor $(A)$. Tables 5-8 summarize the $E_{a}$ and $A$ for the four nut shells. These values refer only to the best-fitted order of the reaction (The $\mathrm{R}^{2}$ for the fitting method was $\geq 0.90$ ). It can be concluded that the highest energy demand (activation energy) is needed for the cellulose decomposition. For the WS, $\mathrm{HS}, \mathrm{PES}$, and PIS at $\beta=5^{\circ} \mathrm{C} \cdot \mathrm{min}^{-1}$, the $E_{a}$ values amounted to $60.3 \pm 2.5 \mathrm{~kJ} \cdot(\mathrm{mol} \cdot \mathrm{K})^{-1}$, $59.3 \pm 0.4 \mathrm{~kJ} \cdot(\mathrm{mol} \cdot \mathrm{K})^{-1}, 53.4 \pm 4.5 \mathrm{~kJ} \cdot(\mathrm{mol} \cdot \mathrm{K})^{-1}$, and $103.8 \pm 22.8 \mathrm{~kJ} \cdot(\mathrm{mol} \cdot \mathrm{K})^{-1}$, respectively. The $E_{a}$ for hemicellulose for nut shells was approximately $30.0-36.2 \mathrm{~kJ} \cdot(\mathrm{mol} \cdot \mathrm{K})^{-1}$, and for the lignin was approximately $19.2-31.5 \mathrm{~kJ} \cdot(\mathrm{mol} \cdot \mathrm{K})^{-1}$. The highest $E_{a}$ demand for cellulose decomposition was also observed in Burhenne studies of spruce biomass [22]. In these studies, $E_{a}$ for cellulose was $236 \mathrm{~kJ} \cdot(\mathrm{mol} \cdot \mathrm{K})^{-1}$, and for hemicellulose and lignin, it was 100 and $40 \mathrm{~kJ} \cdot(\mathrm{mol} \cdot \mathrm{K})^{-1}$, respectively. 
(a)

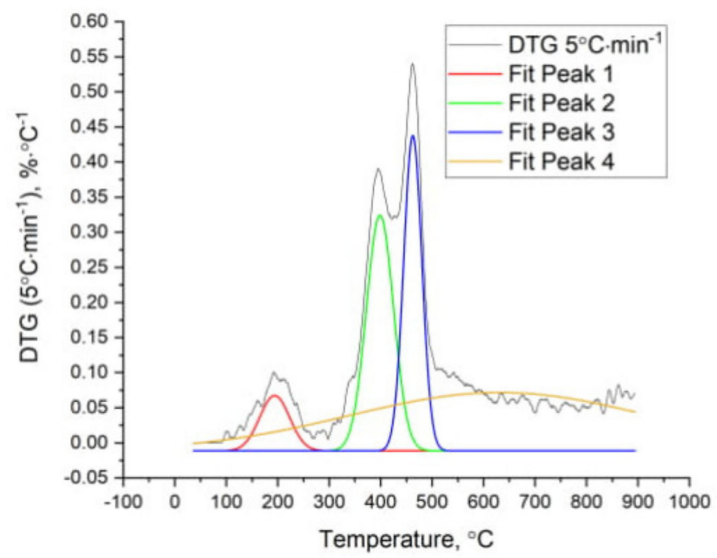

(b)

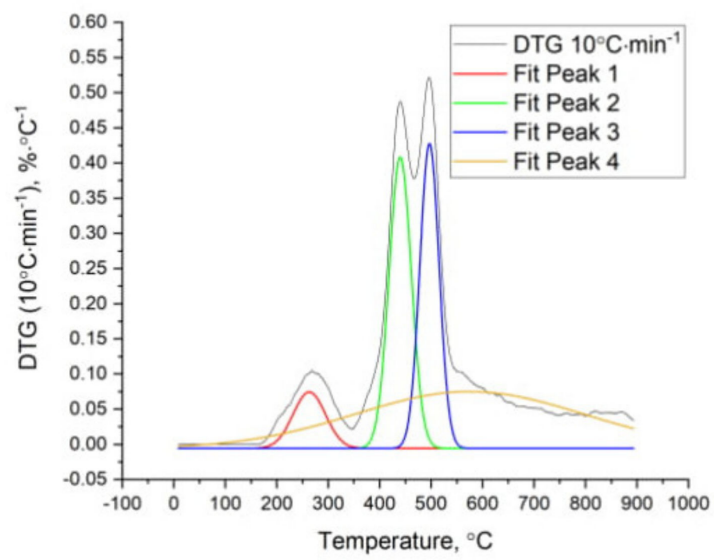

(c)

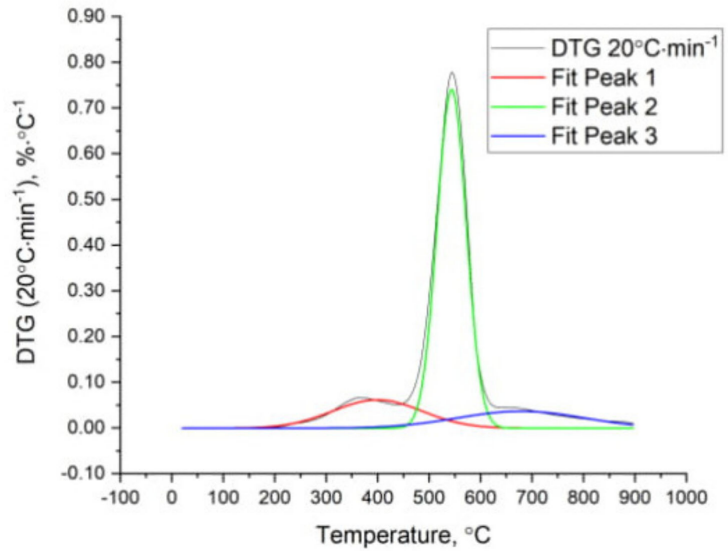

(d)

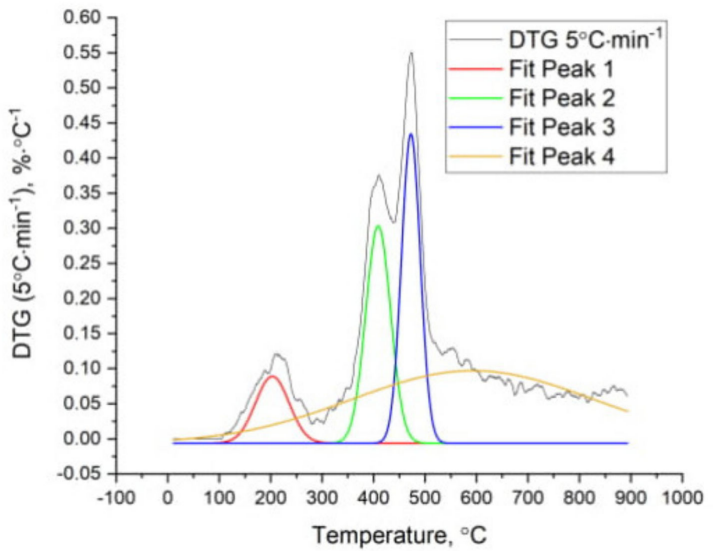

(e)

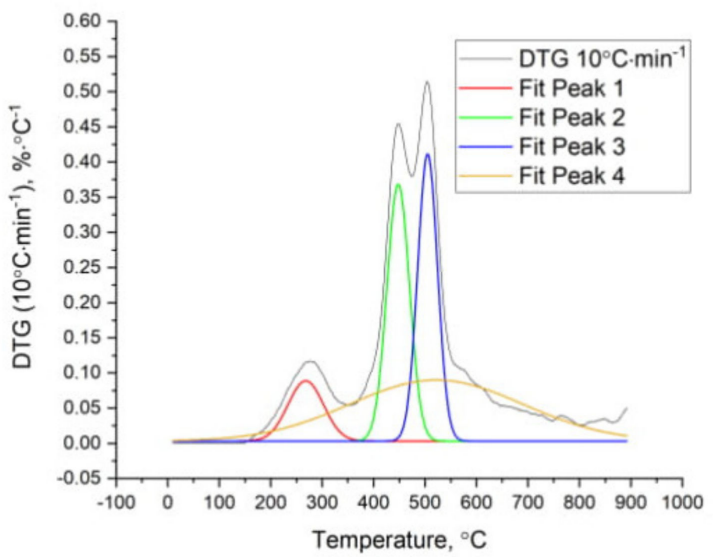

(f)

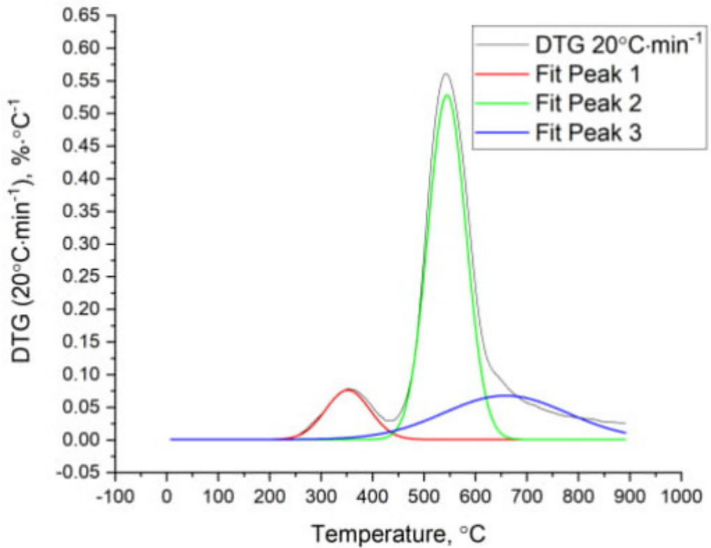

Figure 5. Peak analysis of the WS $(\mathbf{a}-\mathbf{c})$ and HS $(\mathbf{d}-\mathbf{f})$ pyrolysis process at a heating rate $\beta$ of $5{ }^{\circ} \mathrm{C} \cdot \mathrm{min}^{-1}, 10^{\circ} \mathrm{C} \cdot \mathrm{min}^{-1}$, and $20^{\circ} \mathrm{C} \cdot \mathrm{min}^{-1}$. 
(a)

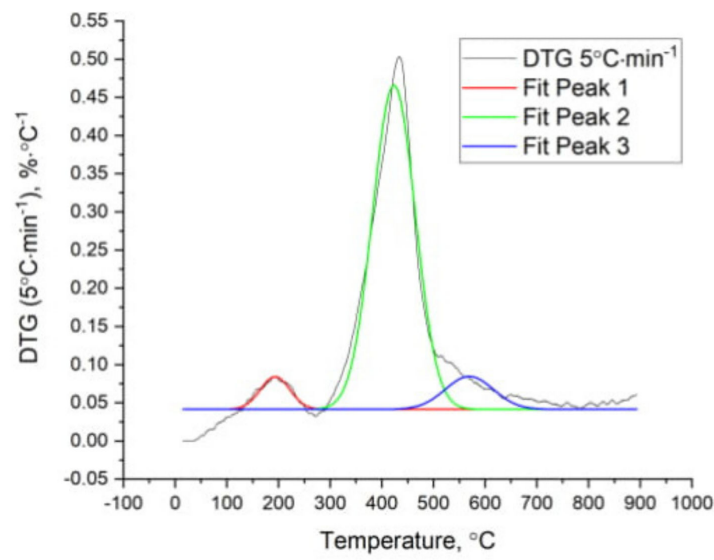

(b)

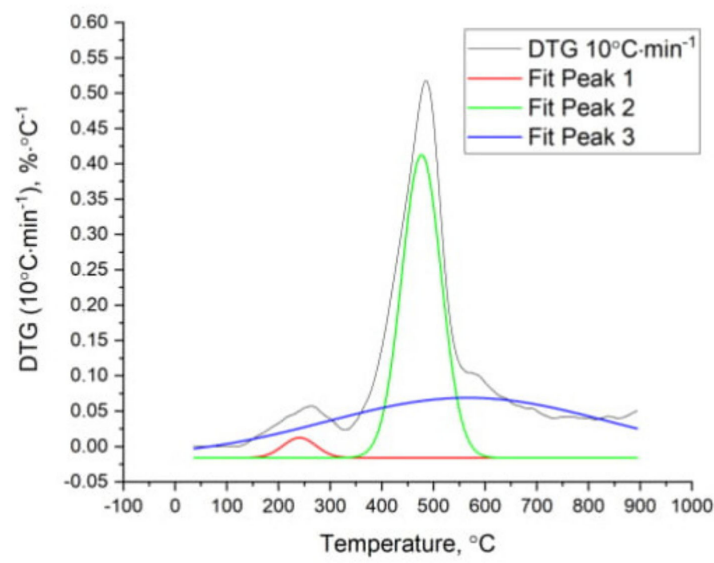

(c)

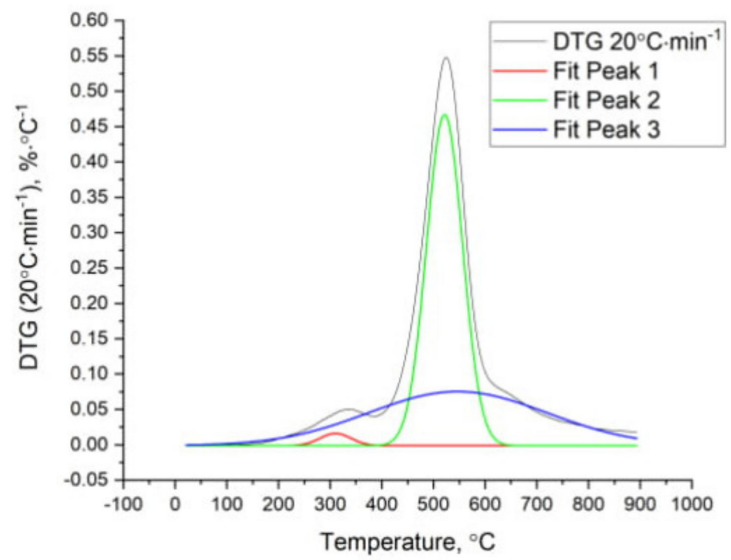

(d)

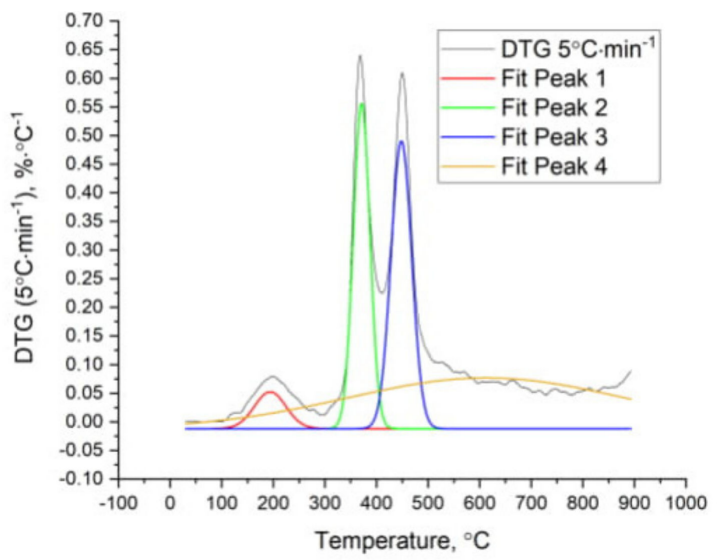

(e)

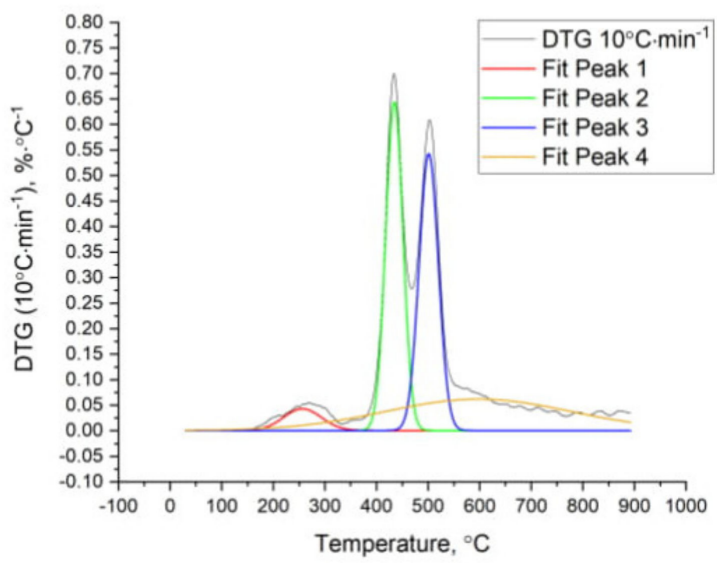

(f)

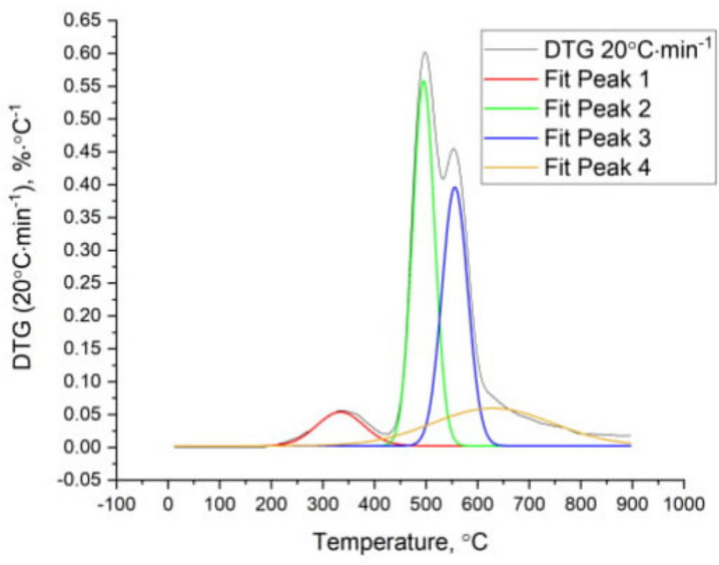

Figure 6. Peaks analysis of the PES (a-c) and PIS (d-f) pyrolysis process at a heating rate $\beta$ of $5{ }^{\circ} \mathrm{C} \cdot \mathrm{min}^{-1}, 10^{\circ} \mathrm{C} \cdot \mathrm{min}^{-1}$, and $20^{\circ} \mathrm{C} \cdot \mathrm{min}^{-1}$. 
Table 5. The activation energy $\left(E_{a}\right)\left[\mathrm{kJ} \cdot(\mathrm{mol} \cdot \mathrm{K})^{-1}\right]$ and pre-exponential factor $(\mathrm{A})\left[\mathrm{s}^{-1}\right]$ for the WS fitted peaks.

\begin{tabular}{|c|c|c|c|c|c|c|c|c|}
\hline & & \multirow{2}{*}{$\begin{array}{c}\text { Kinetic } \\
\text { Parameters }\end{array}$} & \multicolumn{6}{|c|}{ Heating Rate, $\beta$} \\
\hline & & & \multicolumn{2}{|c|}{$5^{\circ} \mathrm{C} \cdot \min ^{-1}$} & \multicolumn{2}{|c|}{$10^{\circ} \mathrm{C} \cdot \min ^{-1}$} & \multicolumn{2}{|c|}{$20^{\circ} \mathrm{C} \cdot \min ^{-1}$} \\
\hline \multirow{10}{*}{ Walnut shell } & \multirow{2}{*}{ Peak 1} & $E_{a}, \mathrm{~kJ} \cdot \mathrm{mol}^{-1} \cdot \mathrm{K}^{-1}$ & \multirow{2}{*}{$\begin{array}{l}\text { From } 148.0^{\circ} \mathrm{C} \pm 9.1 \\
\text { to } 265.0^{\circ} \mathrm{C} \pm 17.7\end{array}$} & $34.5 \pm 9.6$ & \multirow{2}{*}{$\begin{array}{l}\text { From } 196.0^{\circ} \mathrm{C} \pm 5.0 \\
\quad \text { to } 322.7^{\circ} \mathrm{C} \pm 4.0\end{array}$} & $45.3 \pm 2.8$ & \multirow{2}{*}{$\begin{array}{l}\text { From } 232.7^{\circ} \mathrm{C} \pm 12.4 \\
\quad \text { to } 517.3^{\circ} \mathrm{C} \pm 51.7\end{array}$} & $44.8 \pm 4.2$ \\
\hline & & $\mathrm{R}^{2}$ & & 0.9562 & & 0.9678 & & 0.9402 \\
\hline & \multirow{3}{*}{ Peak 2} & $E_{a}, \mathrm{~kJ} \cdot \mathrm{mol}^{-1} \cdot \mathrm{K}^{-1}$ & \multirow{3}{*}{$\begin{array}{l}\text { From } 350.7^{\circ} \mathrm{C} \pm 6.6 \\
\quad \text { to } 446.7^{\circ} \mathrm{C} \pm 4.1\end{array}$} & $56.5 \pm 4.4$ & \multirow{3}{*}{$\begin{array}{l}\text { From } 397.7^{\circ} \mathrm{C} \pm 1.7 \\
\quad \text { to } 485.0^{\circ} \mathrm{C} \pm 2.2\end{array}$} & $74.3 \pm 0.6$ & \multirow{3}{*}{$\begin{array}{l}\text { From } 478.7^{\circ} \mathrm{C} \pm 9.1 \\
\text { to } 609.0^{\circ} \mathrm{C} \pm 12.0\end{array}$} & $140.0 \pm 22.1$ \\
\hline & & $A, \mathrm{~s}^{-1}$ & & $1.05 \pm 0.96 \times 10^{-3}$ & & $1.85 \pm 0.26 \times 10^{-2}$ & & $4.48 \pm 5.34 \times 10^{3}$ \\
\hline & & $\mathrm{R}^{2}$ & & 0.9914 & & 0.9894 & & 0.9847 \\
\hline & \multirow{3}{*}{ Peak 3} & $E a, \mathrm{~kJ} \cdot \mathrm{mol}^{-1} \cdot \mathrm{K}^{-1}$ & \multirow{3}{*}{$\begin{array}{l}\text { From } 425.0^{\circ} \mathrm{C} \pm 1.6 \\
\quad \text { to } 497.7^{\circ} \mathrm{C} \pm 5.7\end{array}$} & $60.3 \pm 2.5$ & \multirow{3}{*}{$\begin{array}{l}\text { From } 461.7^{\circ} \mathrm{C} \pm 1.7 \\
\text { to } 538.3^{\circ} \mathrm{C} \pm 3.3\end{array}$} & $74.2 \pm 1.5$ & \multirow{3}{*}{$\begin{array}{l}\text { From } 375.7^{\circ} \mathrm{C} \pm 90.4 \\
\text { to } 889.7^{\circ} \mathrm{C} \pm 1.9\end{array}$} & $65.0 \pm 7.4$ \\
\hline & & $A, \mathrm{~s}^{-1}$ & & $1.48 \pm 0.58 \times 10^{-3}$ & & $1.84 \pm 0.49 \times 10^{-2}$ & & $4.17 \pm 2.81 \times 10^{-3}$ \\
\hline & & $\mathrm{R}^{2}$ & & 0.9887 & & 0.9887 & & 0.9430 \\
\hline & \multirow[b]{2}{*}{ Peak 4} & $E_{a}, \mathrm{~kJ} \cdot \mathrm{mol}^{-1} \cdot \mathrm{K}^{-1}$ & \multirow{2}{*}{$\begin{array}{l}\text { From } 155.3^{\circ} \mathrm{C} \pm 53.7 \\
\text { to } 852.0{ }^{\circ} \mathrm{C} \pm 55.9\end{array}$} & $27.9 \pm 1.2$ & \multirow{2}{*}{$\begin{array}{l}\text { From } 176.3^{\circ} \mathrm{C} \pm 5.6 \\
\quad \text { to } 890.7^{\circ} \mathrm{C} \pm 1.9\end{array}$} & $36.8 \pm 0.7$ & \multirow[b]{2}{*}{-} & - \\
\hline & & $A, \mathrm{~s}^{-1}$ & & $2.73 \pm 1.05 \times 10^{-6}$ & & $2.15 \pm 0.25 \times 10^{-5}$ & & - \\
\hline
\end{tabular}

Table 6. The activation energy (Ea) $\left[\mathrm{kJ} \cdot(\mathrm{mol} \cdot \mathrm{K})^{-1}\right]$ and pre-exponential factor $(\mathrm{A})\left[\mathrm{s}^{-1}\right]$ for the HS fitted peaks.

\begin{tabular}{|c|c|c|c|c|c|c|c|c|}
\hline & & \multirow{2}{*}{$\begin{array}{c}\text { Kinetic } \\
\text { Parameters }\end{array}$} & \multicolumn{6}{|c|}{ Heating Rate, $\beta$} \\
\hline & & & \multicolumn{2}{|c|}{$5^{\circ} \mathrm{C} \cdot \min ^{-1}$} & \multicolumn{2}{|c|}{$10^{\circ} \mathrm{C} \cdot \min ^{-1}$} & \multicolumn{2}{|c|}{$20^{\circ} \mathrm{C} \cdot \min ^{-1}$} \\
\hline \multirow{6}{*}{ Hazelnut shell } & \multirow{3}{*}{ Peak 1} & $E_{a}, \mathrm{~kJ} \cdot \mathrm{mol}^{-1} \cdot \mathrm{K}^{-1}$ & \multirow{3}{*}{$\begin{array}{c}\text { From } 145.7^{\circ} \mathrm{C} \pm 8.8 \\
\text { to } 274.3^{\circ} \mathrm{C} \pm 15.8\end{array}$} & $36.2 \pm 9.8$ & \multirow{3}{*}{$\begin{array}{l}\text { From } 198.7^{\circ} \mathrm{C} \pm 3.7 \\
\quad \text { to } 330.7^{\circ} \mathrm{C} \pm 4.9\end{array}$} & $48.7 \pm 7.2$ & \multirow{3}{*}{$\begin{array}{l}\text { From } 272.3^{\circ} \mathrm{C} \pm 6.2 \\
\quad \text { to } 448.0^{\circ} \mathrm{C} \pm 8.6\end{array}$} & $51.5 \pm 8.1$ \\
\hline & & $A, \mathrm{~s}^{-1}$ & & $2.70 \pm 3.43 \times 10^{-4}$ & & $1.56 \pm 1.97 \times 10^{-3}$ & & $9.81 \pm 12.6 \times 10^{-3}$ \\
\hline & & $\mathrm{R}^{2}$ & & $0.9332 \pm 0.0329$ & & $0.9329 \pm 0.0251$ & & $0.8986 \pm 0.0042$ \\
\hline & \multirow{3}{*}{ Peak 2} & $E_{a}, \mathrm{~kJ} \cdot \mathrm{mol}^{-1} \cdot \mathrm{K}^{-1}$ & \multirow{3}{*}{$\begin{array}{l}\text { From } 358.8^{\circ} \mathrm{C} \pm 3.6 \\
\text { to } 449.7^{\circ} \mathrm{C} \pm 5.2\end{array}$} & $53.8 \pm 3.9$ & \multirow{3}{*}{$\begin{array}{l}\text { From } 403.3^{\circ} \mathrm{C} \pm 0.9 \\
\text { to } 487.3^{\circ} \mathrm{C} \pm 3.4\end{array}$} & $75.8 \pm 8.6$ & \multirow{3}{*}{$\begin{array}{l}\text { From } 477.7^{\circ} \mathrm{C} \pm 5.7 \\
\quad \text { to } 621.7^{\circ} \mathrm{C} \pm 2.5\end{array}$} & $113.9 \pm 2.4$ \\
\hline & & $A, \mathrm{~s}^{-1}$ & & $5.24 \pm 4.22 \times 10^{-4}$ & & $5.07 \pm 5.76 \times 10^{-2}$ & & $5.57 \pm 1.72 \times 10^{0}$ \\
\hline & & $\mathrm{R}^{2}$ & & $0.9935 \pm 0.0003$ & & $0.9904 \pm 0.0000$ & & $0.9859 \pm 0.0007$ \\
\hline
\end{tabular}


Table 6. Cont.

\begin{tabular}{|c|c|c|c|c|c|c|c|}
\hline & \multirow{2}{*}{$\begin{array}{c}\text { Kinetic } \\
\text { Parameters }\end{array}$} & \multicolumn{6}{|c|}{ Heating Rate, $\beta$} \\
\hline & & \multicolumn{2}{|c|}{$5^{\circ} \mathrm{C} \cdot \min ^{-1}$} & \multicolumn{2}{|c|}{$10^{\circ} \mathrm{C} \cdot \min ^{-1}$} & \multicolumn{2}{|c|}{$20^{\circ} \mathrm{C} \cdot \min ^{-1}$} \\
\hline \multirow{2}{*}{ Peak 3} & $E_{a}, \mathrm{~kJ} \cdot \mathrm{mol}^{-1} \cdot \mathrm{K}^{-1}$ & \multirow{2}{*}{$\begin{array}{l}\text { From } 426.7^{\circ} \mathrm{C} \pm 7.8 \\
\text { to } 502.7^{\circ} \mathrm{C} \pm 4.6\end{array}$} & $59.3 \pm 0.4$ & \multirow{2}{*}{$\begin{array}{l}\text { From } 462.0^{\circ} \mathrm{C} \pm 2.9 \\
\quad \text { to } 541.3^{\circ} \mathrm{C} \pm 3.1\end{array}$} & $75.5 \pm 2.5$ & \multirow{2}{*}{$\begin{array}{l}\text { From } 426.7^{\circ} \mathrm{C} \pm 9.0 \\
\text { to } 882.7^{\circ} \mathrm{C} \pm 11.1\end{array}$} & $65.4 \pm 0.9$ \\
\hline & $\mathrm{R}^{2}$ & & $0.9892 \pm 0.0012$ & & $0.9897 \pm 0.0007$ & & $0.9503 \pm 0.0019$ \\
\hline \multirow{3}{*}{ Peak 4} & $E_{a}, \mathrm{~kJ} \cdot \mathrm{mol}^{-1} \cdot \mathrm{K}^{-1}$ & \multirow{3}{*}{$\begin{array}{c}\text { From } 173.0^{\circ} \mathrm{C} \pm 61 \\
\text { to } 846.7^{\circ} \mathrm{C} \pm 64.1\end{array}$} & $28.2 \pm 1.4$ & \multirow{3}{*}{$\begin{array}{c}\text { From } 201 .{ }^{\circ} \mathrm{C} \pm 30.1 \\
\text { to } 880.7^{\circ} \mathrm{C} \pm 16.0\end{array}$} & $36.8 \pm 0.9$ & \multirow{3}{*}{-} & - \\
\hline & $A, \mathrm{~s}^{-1}$ & & $2.87 \pm 1.14 \times 10^{-6}$ & & $2.07 \pm 0.25 \times 10^{-5}$ & & - \\
\hline & $\mathrm{R}^{2}$ & & $0.9422 \pm 0.036$ & & $0.9593 \pm 0.0111$ & & - \\
\hline
\end{tabular}

Table 7. Activation energy $\left(E_{a}\right)\left[\mathrm{kJ} \cdot(\mathrm{mol} \cdot \mathrm{K})^{-1}\right]$ and pre-exponential factor $(\mathrm{A})\left[\mathrm{s}^{-1}\right]$ for the PES fitted peaks.

\begin{tabular}{|c|c|c|c|c|c|c|c|c|}
\hline & & \multirow{2}{*}{$\begin{array}{c}\text { Kinetic } \\
\text { Parameters }\end{array}$} & \multicolumn{6}{|c|}{ Heating Rate, $\beta$} \\
\hline & & & \multicolumn{2}{|c|}{$5^{\circ} \mathrm{C} \cdot \min ^{-1}$} & \multicolumn{2}{|c|}{$10^{\circ} \mathrm{C} \cdot \min ^{-1}$} & \multicolumn{2}{|c|}{$20^{\circ} \mathrm{C} \cdot \min ^{-1}$} \\
\hline \multirow{12}{*}{ Peanut shell } & \multirow{3}{*}{ Peak 1} & $E_{a}, \mathrm{~kJ} \cdot \mathrm{mol}^{-1} \cdot \mathrm{K}^{-1}$ & \multirow{3}{*}{$\begin{array}{l}\text { From } 131.3^{\circ} \mathrm{C} \pm 11.1 \\
\quad \text { to } 251.0^{\circ} \mathrm{C} \pm 2.4\end{array}$} & $34.3 \pm 13.0$ & \multirow{3}{*}{$\begin{array}{l}\text { From } 183.3^{\circ} \mathrm{C} \pm 9.7 \\
\text { to } 306.7^{\circ} \mathrm{C} \pm 3.9\end{array}$} & $36.7 \pm 9.7$ & \multirow{3}{*}{$\begin{array}{l}\text { From } 245.7^{\circ} \mathrm{C} \pm 2.9 \\
\quad \text { to } 397.7^{\circ} \mathrm{C} \pm 3.9\end{array}$} & $47.2 \pm 14.1$ \\
\hline & & $A, \mathrm{~s}^{-1}$ & & $2.00 \pm 2.33 \times 10^{-4}$ & & $1.92 \pm 2.62 \times 10^{-4}$ & & $2.41 \pm 3.39 \times 10^{-3}$ \\
\hline & & $R^{2}$ & & 0.9316 & & 0.9617 & & 0.9488 \\
\hline & \multirow{3}{*}{ Peak 2} & $E_{a}, \mathrm{~kJ} \cdot \mathrm{mol}^{-1} \cdot \mathrm{K}^{-1}$ & \multirow{3}{*}{$\begin{array}{l}\text { From } 350.0^{\circ} \mathrm{C} \pm 7.9 \\
\text { to } 505.7^{\circ} \mathrm{C} \pm 3.3\end{array}$} & $53.4 \pm 4.5$ & \multirow{3}{*}{$\begin{array}{l}\text { From } 399.3^{\circ} \mathrm{C} \pm 4.6 \\
\text { to } 546.7^{\circ} \mathrm{C} \pm 5.8\end{array}$} & $75.5 \pm 2.9$ & \multirow{3}{*}{$\begin{array}{l}\text { From } 475.3^{\circ} \mathrm{C} \pm 17.6 \\
\text { to } 593.0{ }^{\circ} \mathrm{C} \pm 14.4\end{array}$} & $116.0 \pm 9.9$ \\
\hline & & $A, \mathrm{~s}^{-1}$ & & $4.62 \pm 3.42 \times 10^{-4}$ & & $2.22 \pm 0.87 \times 10^{-2}$ & & $2.84 \pm 3.46 \times 10^{1}$ \\
\hline & & $\mathrm{R}^{2}$ & & 0.9868 & & 0.9892 & & 0.9920 \\
\hline & \multirow{3}{*}{ Peak 3} & $E_{a}, \mathrm{~kJ} \cdot \mathrm{mol}^{-1} \cdot \mathrm{K}^{-1}$ & \multirow{3}{*}{$\begin{array}{l}\text { From } 426.7^{\circ} \mathrm{C} \pm 39.7 \\
\text { to } 688.3^{\circ} \mathrm{C} \pm 14.3\end{array}$} & $19.2 \pm 7.0$ & \multirow{3}{*}{$\begin{array}{l}\text { From } 142.7^{\circ} \mathrm{C} \pm 33.2 \\
\quad \text { to } 892.7^{\circ} \mathrm{C} \pm 0.5\end{array}$} & $36.3 \pm 2.5$ & \multirow{3}{*}{$\begin{array}{l}\text { From } 217.3^{\circ} \mathrm{C} \pm 21.3 \\
\quad \text { to } 863.7^{\circ} \mathrm{C} \pm 28.1\end{array}$} & $53.1 \pm 4.4$ \\
\hline & & $A, \mathrm{~s}^{-1}$ & & $9.34 \pm 9.65 \times 10^{-3}$ & & $1.99 \pm 0.69 \times 10^{-5}$ & & $5.53 \pm 3.82 \times 10^{-4}$ \\
\hline & & $R^{2}$ & & 0.9009 & & 0.9666 & & 0.9718 \\
\hline & \multirow{3}{*}{ Peak 4} & $E_{a}, \mathrm{~kJ} \cdot \mathrm{mol}^{-1} \cdot \mathrm{K}^{-1}$ & & - & & - & & - \\
\hline & & $A, \mathrm{~s}^{-1}$ & - & - & - & - & - & - \\
\hline & & $\mathrm{R}^{2}$ & & - & & - & & - \\
\hline
\end{tabular}


Table 8. Activation energy $\left(E_{a}\right)\left[\mathrm{kJ} \cdot(\mathrm{mol} \cdot \mathrm{K})^{-1}\right]$ and pre-exponential factor $(\mathrm{A})\left[\mathrm{s}^{-1}\right]$ for the PIS fitted peaks.

\begin{tabular}{|c|c|c|c|c|c|c|c|c|}
\hline & & \multirow{2}{*}{$\begin{array}{c}\text { Kinetic } \\
\text { Parameters }\end{array}$} & \multicolumn{6}{|c|}{ Heating Rate, $\beta$} \\
\hline & & & \multicolumn{2}{|c|}{$5^{\circ} \mathrm{C} \cdot \min ^{-1}$} & \multicolumn{2}{|c|}{$10^{\circ} \mathrm{C} \cdot \min ^{-1}$} & \multicolumn{2}{|c|}{$20^{\circ} \mathrm{C} \cdot \min ^{-1}$} \\
\hline \multirow{10}{*}{ Pistachio shell } & \multirow{2}{*}{ Peak 1} & $E_{a}, \mathrm{~kJ} \cdot \mathrm{mol}^{-1} \cdot \mathrm{K}^{-1}$ & \multirow{2}{*}{$\begin{array}{l}\text { From } 137.0{ }^{\circ} \mathrm{C} \pm 27.9 \\
\text { to } 266.0{ }^{\circ} \mathrm{C} \pm 7.9\end{array}$} & $30.0 \pm 6.6$ & \multirow{2}{*}{$\begin{array}{l}\text { From } 204.3^{\circ} \mathrm{C} \pm 22.8 \\
\quad \text { to } 328.0{ }^{\circ} \mathrm{C} \pm 5.4\end{array}$} & $43.7 \pm 9.1$ & \multirow{2}{*}{$\begin{array}{l}\text { From } 255.0^{\circ} \mathrm{C} \pm 11.2 \\
\quad \text { to } 434.3^{\circ} \mathrm{C} \pm 9.9\end{array}$} & $51.5 \pm 9.3$ \\
\hline & & $R^{2}$ & & 0.9549 & & 0.9289 & & 0.9226 \\
\hline & \multirow{3}{*}{ Peak 2} & $E_{a}, \mathrm{~kJ} \cdot \mathrm{mol}^{-1} \cdot \mathrm{K}^{-1}$ & \multirow{3}{*}{$\begin{array}{l}\text { From } 350.7^{\circ} \mathrm{C} \pm 8.7 \\
\quad \text { to } 414.0^{\circ} \mathrm{C} \pm 8.3\end{array}$} & $103.8 \pm 22.8$ & \multirow{3}{*}{$\begin{array}{l}\text { From } 400.0^{\circ} \mathrm{C} \pm 9.9 \\
\text { to } 461.3{ }^{\circ} \mathrm{C} \pm 11.6\end{array}$} & $152.5 \pm 19.8$ & \multirow{3}{*}{$\begin{array}{l}\text { From } 456.7^{\circ} \mathrm{C} \pm 2.6 \\
\quad \text { to } 540.7^{\circ} \mathrm{C} \pm 2.6\end{array}$} & $150.3 \pm 5.8$ \\
\hline & & $A, \mathrm{~s}^{-1}$ & & $9.11 \pm 12.9 \times 10^{2}$ & & $5.05 \pm 7.01 \times 10^{5}$ & & $4.29 \pm 3.68 \times 10^{3}$ \\
\hline & & $\mathrm{R}^{2}$ & & 0.9667 & & 0.9636 & & 0.9594 \\
\hline & \multirow{3}{*}{ Peak 3} & $E_{a}, \mathrm{~kJ} \cdot \mathrm{mol}^{-1} \cdot \mathrm{K}^{-1}$ & \multirow{3}{*}{$\begin{array}{l}\text { From } 417.3^{\circ} \mathrm{C} \pm 6.6 \\
\quad \text { to } 494.3^{\circ} \mathrm{C} \pm 4.5\end{array}$} & $63.0 \pm 6.5$ & \multirow{3}{*}{$\begin{array}{l}\text { From } 454.7^{\circ} \mathrm{C} \pm 6.6 \\
\text { to } 535.3^{\circ} \mathrm{C} \pm 10.8\end{array}$} & $80.2 \pm 5.5$ & \multirow{3}{*}{$\begin{array}{l}\text { From } 508.7^{\circ} \mathrm{C} \pm 2.1 \\
\quad \text { to } 607.3^{\circ} \mathrm{C} \pm 1.2\end{array}$} & $96.1 \pm 3.3$ \\
\hline & & $A, \mathrm{~s}^{-1}$ & & $5.24 \pm 5.96 \times 10^{-3}$ & & $7.77 \pm 4.80 \times 10^{-2}$ & & $6.21 \pm 3.31 \times 10^{-1}$ \\
\hline & & $\mathrm{R}^{2}$ & & 0.9768 & & 0.9785 & & 0.9805 \\
\hline & \multirow[b]{2}{*}{ Peak 4} & $E_{a}, \mathrm{~kJ} \cdot \mathrm{mol}^{-1} \cdot \mathrm{K}^{-1}$ & \multirow{2}{*}{$\begin{array}{c}\text { From } 155.3^{\circ} \mathrm{C} \pm 49.4 \\
\text { to } 865.7^{\circ} \mathrm{C} \pm 29.2\end{array}$} & $31.5 \pm 5.8$ & \multirow{2}{*}{$\begin{array}{l}\text { From } 239.7^{\circ} \mathrm{C} \pm 1.7 \\
\quad \text { to } 888.0^{\circ} \mathrm{C} \pm 2.9\end{array}$} & $45.1 \pm 5.2$ & \multirow{2}{*}{$\begin{array}{l}\text { From } 405.7^{\circ} \mathrm{C} \pm 6.6 \\
\quad \text { to } 860.3{ }^{\circ} \mathrm{C} \pm 4.1\end{array}$} & $67.4 \pm 1.3$ \\
\hline & & $A, \mathrm{~s}^{-1}$ & & $8.69 \pm 9.01 \times 10^{-6}$ & & $1.31 \pm 1.20 \times 10^{-4}$ & & $3.96 \pm 0.61 \times 10^{-3}$ \\
\hline
\end{tabular}


The increase in the $E_{a}$ during the cellulose decomposition was observed with the increase of $\beta$. For the WS, $E_{a}$ was 74.3 and $140.0 \mathrm{~kJ} \cdot(\mathrm{mol} \cdot \mathrm{K})^{-1}$ for the $\beta$ of 10 and $20^{\circ} \mathrm{C} \cdot \mathrm{min}^{-1}$, respectively. In the case of the HS, $E_{a}$ was $75.8 \mathrm{~kJ} \cdot(\mathrm{mol} \cdot \mathrm{K})^{-1}\left(\beta=10^{\circ} \mathrm{C} \cdot \mathrm{min}^{-1}\right)$ and $113.9 \mathrm{~kJ} \cdot(\mathrm{mol} \cdot \mathrm{K})^{-1}\left(\beta=20^{\circ} \mathrm{C} \cdot \mathrm{min}^{-1}\right)$. Whereas, for PES, the $E_{a}$ was $75.5 \mathrm{~kJ} \cdot(\mathrm{mol} \cdot \mathrm{K})^{-1}$ $\left(\beta=10^{\circ} \mathrm{C} \cdot \mathrm{min}^{-1}\right)$ and $116.0 \mathrm{~kJ} \cdot(\mathrm{mol} \cdot \mathrm{K})^{-1}\left(\beta=20^{\circ} \mathrm{C} \cdot \mathrm{min}^{-1}\right)$. Finally, for the PIS, the $E_{a}$ amounted to $152.5 \mathrm{~kJ} \cdot(\mathrm{mol} \cdot \mathrm{K})^{-1}\left(\beta=10^{\circ} \mathrm{C} \cdot \mathrm{min}^{-1}\right)$ and $150.3 \mathrm{~kJ} \cdot(\mathrm{mol} \cdot \mathrm{K})^{-1}\left(\beta=20^{\circ} \mathrm{C} \cdot \mathrm{min}^{-1}\right)$. A similar dependence was also noted for the lignin decomposition stage.

\subsection{Conversion Rate and the Kinetic Parameters of the Pyrolysis Process}

No significant differences were observed for the conversion rate $(\alpha)$ vs. T and the type of nuts shell (Figure 7). It can be assumed that WS, HS, PES, and PIS have very similar thermal decomposition characteristics. Their hemicellulose, cellulose, and lignin degradation started at a similar range of temperatures. The materials reached comparable $\alpha$ at the related T. Thus, based only on the analysis of $\alpha$, it may be concluded that WS, HS, PES, and PIS belonging to nut shells biomass type were characterized by similar thermal degradation kinetics.

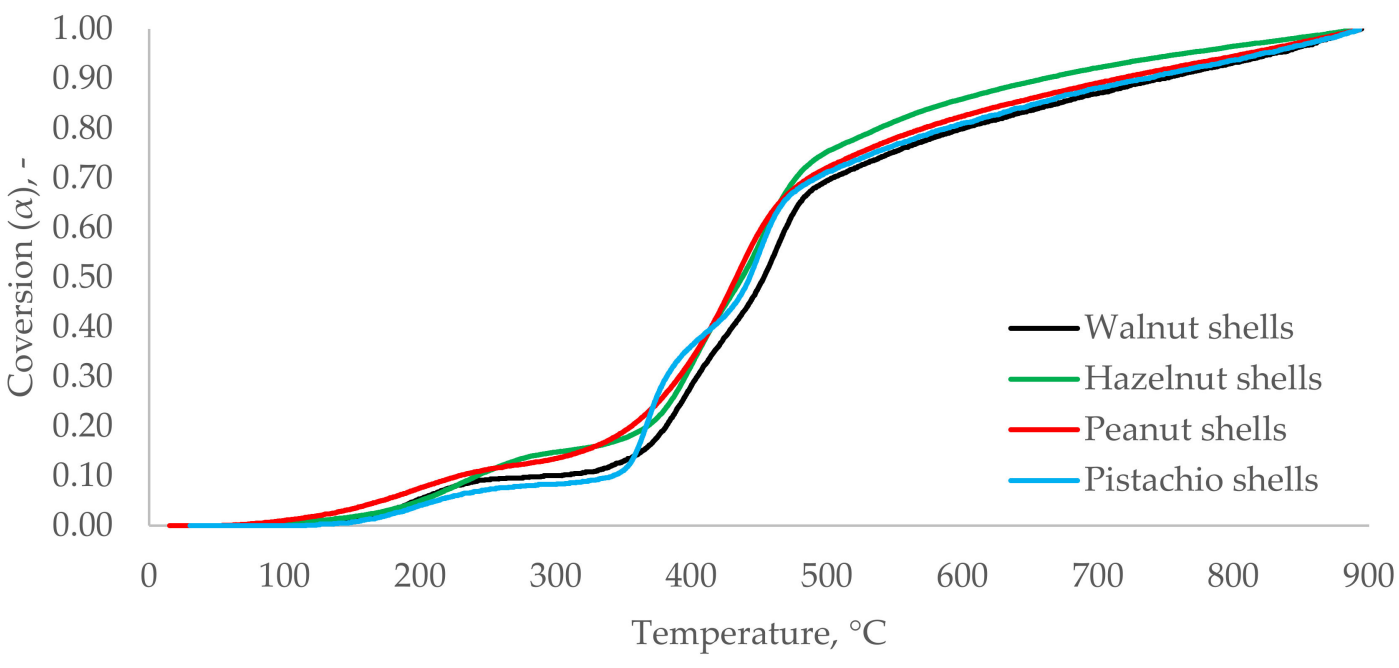

(a)

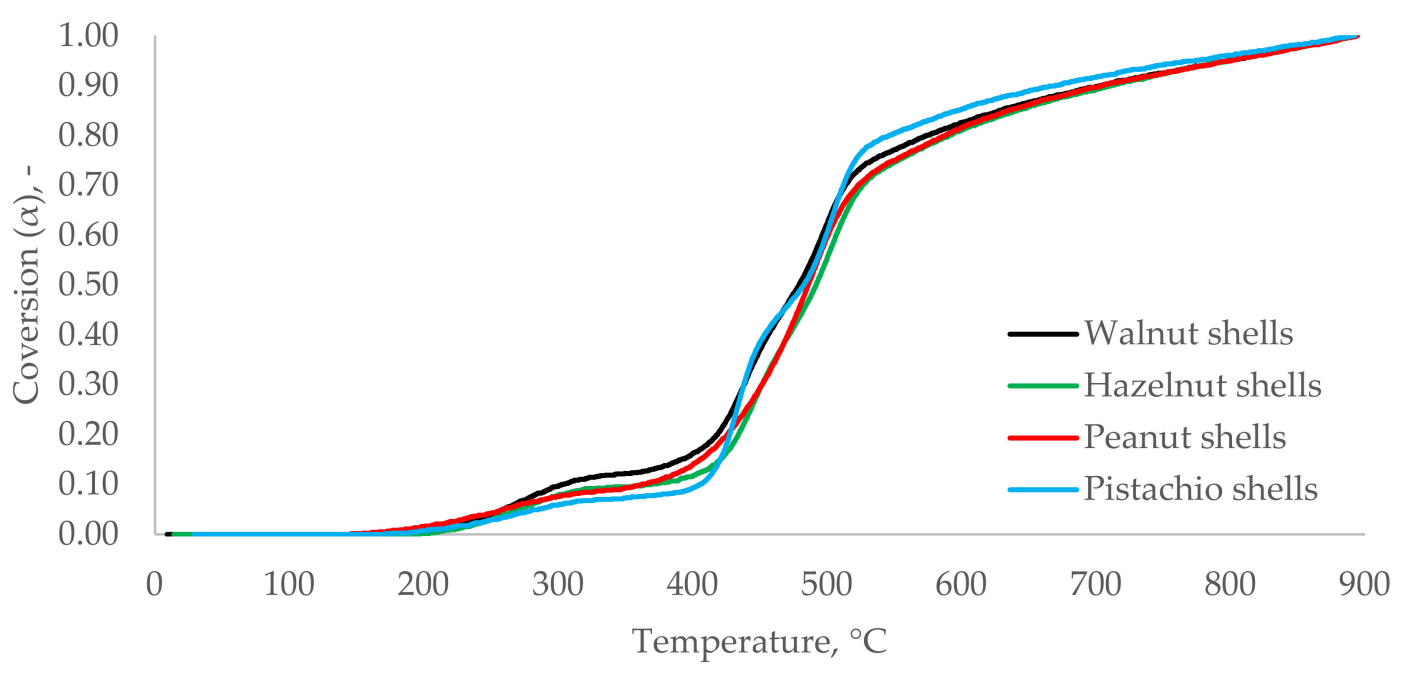

(b)

Figure 7. Cont. 


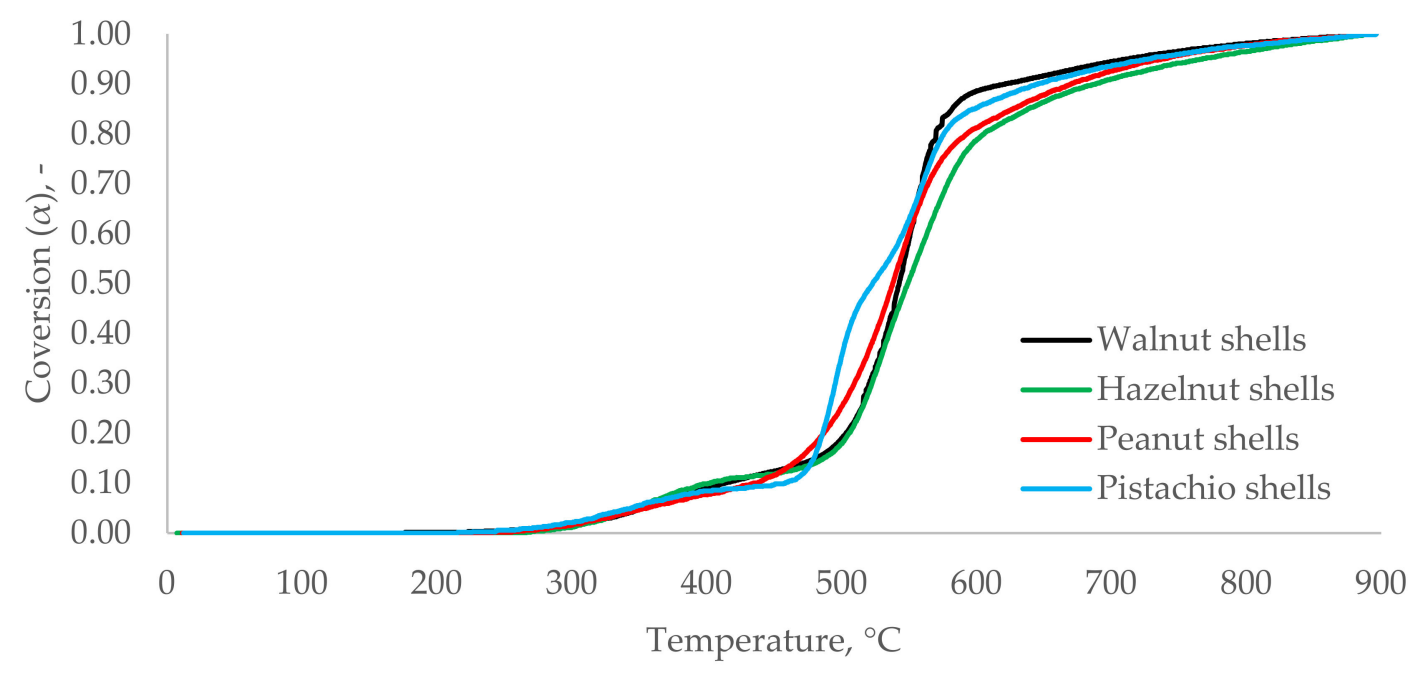

(c)

Figure 7. Conversion rates $[\alpha(\mathrm{T})]$ for WS, HS, PES, and PIS in heating rates $5{ }^{\circ} \mathrm{C} \cdot \mathrm{min}^{-1}(\mathbf{a}), 10^{\circ} \mathrm{C} \cdot \mathrm{min}^{-1}(\mathbf{b})$, and $20{ }^{\circ} \mathrm{C} \cdot \mathrm{min}^{-1}(\mathbf{c})$.

However, using the more detailed analysis of kinetic, some differences may be observed. Tables S1-S4 (Supplementary Materials), the values of $E_{a}$ and $A$ for $\alpha$ with the interval of 0.05 are shown. The TGA from 30 to $900{ }^{\circ} \mathrm{C}$ was fitted into the $n=1.5$ reaction order $\left(R^{2} \geq 0.97\right)$. Again, the most energy-demanding reaction in the thermal degradation of nut shells was the decomposition of cellulose. This stage had the highest energy demand, so the $E_{a}$ of each nut shells was determined for the second peak obtained from DTG analysis. The $E_{a}$ for nut shells was then estimated using the values from Tables 5 and 6 . The resulting $E_{a}\left(\beta=5{ }^{\circ} \mathrm{C} \cdot \mathrm{min}^{-1}\right)$ was $60.3 \pm 2.5 \mathrm{~kJ} \cdot(\mathrm{mol} \cdot \mathrm{K})^{-1}(\mathrm{WS}), 59.3 \pm 0.4 \mathrm{~kJ} \cdot(\mathrm{mol} \cdot \mathrm{K})^{-1}$ (HS), $53.4 \pm 4.5 \mathrm{~kJ} \cdot(\mathrm{mol} \cdot \mathrm{K})^{-1}$ (PES), and $103.8 \pm 22.8 \mathrm{~kJ} \cdot(\mathrm{mol} \cdot \mathrm{K})^{-1}$ (PIS). Likewise, the $E_{a}$ increased with the increase of $\beta$ (Tables 5 and 6).

Other studies describe an application of TGA to nut shells. For the HS, the $E_{a}$ amounted to $215 \mathrm{~kJ} \cdot(\mathrm{mol} \cdot \mathrm{K})^{-1}$ [61]. The differences in results may arise from different sets of $\beta$ and other kinetic models used. In this study [61], the FWO model was applied. Analyzing the $E_{a}$ of HS determined by the Coats-Redfern method, the similarity of the resulting values can be confirmed. In the Haikiri-Acma study [62], the $E_{a}$ for HS was between 33 and $58 \mathrm{~kJ} \cdot(\mathrm{mol} \cdot \mathrm{K})^{-1}$, depending on the particle size. Some differences can be observed when comparing these data with ours. In the Demirbas study [63], the HS activation energy was from 89 to $129 \mathrm{~kJ} \cdot(\mathrm{mol} \cdot \mathrm{K})^{-1}$. For the other materials (e.g., WS) a similarity in kinetic parameters was also observed. The values of $E_{a}$ ranged from 45.6 to $78.4 \mathrm{~kJ} \cdot(\mathrm{mol} \cdot \mathrm{K})^{-1}[64]$ and were very close to the data presented in this work. Acikalin [65] studied the kinetics of the PIS. The $E_{a}$ for PIS was from 121 to $187 \mathrm{~kJ} \cdot(\mathrm{mol} \cdot \mathrm{K})^{-1}$ (modelfitting method), and $153 \mathrm{~kJ} \cdot(\mathrm{mol} \cdot \mathrm{K})^{-1}$ (FWO method). The $A$ for the tested materials in this study $\left(\beta=5^{\circ} \mathrm{C} \cdot \mathrm{min}^{-1}\right)$ for different conversion rates was $5.2 \pm 2.9 \times 10^{-9}$ to $4.4 \pm 5.4 \times 10^{4}, 6.1 \pm 6.7 \times 10^{-9}$ to $1.0 \pm 1.2 \times 10^{4}, 9.7 \pm 2.2 \times 10^{-8}$ to $4.9 \pm 6.8 \times 10^{5}$, and $8.3 \pm 12 \times 10^{-8}$ to $2.2 \pm 3.1 \times 10^{8}$ for WS, HS, PES, and PIS, respectively. The $A$ for the other $\beta$ is presented in Tables S1-S4. The significant difference between the $E_{a}$ for PIS and other nut shells may be from the different content of the hemicellulose and cellulose. The PIS consists of $40 \%$ cellulose and $34 \%$ hemicellulose [66] in comparison to the WS, HS, and PES, where the cellulose content ranges from $25-35 \%$, and hemicellulose content ranges from $8-30 \%$ [37,41].

Kinetic parameters play an important role in designing the experimental processes and bio-reactors. Based on the kinetic parameters of thermal degradation of biomass materials, it is possible to estimate the temperature range of the lignocellulose degradation and heat demand to start the decomposition of the material. This is crucial from the practical point of view to determine the production costs. Moreover, the knowledge of the kinetic parameters 
can be useful to optimize the process conditions to obtain the final products with specific properties.

\section{Conclusions}

Raw nut shells from walnuts (WS), hazelnuts (HS), peanuts (PES), and pistachios (PIS) have a remarkable energy potential (their average HHV was approximately $19.4 \mathrm{MJ} \cdot \mathrm{kg}^{-1}$, excluding the PIS, for which HHV $=17.8 \mathrm{MJ} \cdot \mathrm{kg}^{-1}$. After the thermal treatment of nut shells (torrefaction, pyrolysis), the HHV significantly increased up to ca. $30 \mathrm{MJ} \cdot \mathrm{kg}^{-1}$. However, their thermal treatment requires basic knowledge of kinetic parameters to facilitate the design of bioreactors and to optimize the conditions for obtaining specific properties of the processed waste.

The ultimate analysis showed that the elemental characteristics of nut shells were similar. Their carbon content was between $44 \%$ (PIS) and $49 \%$ (HS, PES), and the oxygen content was $39.6-44.8 \%$. The heating rate $(\beta)$ in the process of thermal treatment of waste biomass affected the values of kinetic parameters of the process (especially $E_{a}$ ). Faster $\beta$ resulted in higher $E_{a}$. No significant differences were observed for the conversion rate $(\alpha)$ vs. temperature and the type of nuts shells.

The cellulose content had a significant impact on the $E_{a}$. The highest $E_{a}$ was needed at the second stage of reaction, which was related to the cellulose decomposition. At this range of temperatures, the highest mass (volatile matter) loss and the fastest $\alpha$ were observed.

The nut shells had a characteristic pattern with three reaction stages characteristic for hemicellulose, cellulose, and lignin decomposition. The hemicellulose decomposition took place at 140 to $264^{\circ} \mathrm{C}\left(\beta=5^{\circ} \mathrm{C} \cdot \mathrm{min}^{-1}\right)$ for all nut shells. However, depending on the $\beta$, it shifted from 196 to $322^{\circ} \mathrm{C}$ and from 252 to $449^{\circ} \mathrm{C}$ for $\beta=10^{\circ} \mathrm{C} \cdot \mathrm{min}^{-1}$ and $\beta=20^{\circ} \mathrm{C} \cdot \mathrm{min}^{-1}$, respectively. The degradation of cellulose for WS and HS (at $\beta=5^{\circ} \mathrm{C} \cdot \mathrm{min}^{-1}$ ) and for PIS (at both 5 and $10^{\circ} \mathrm{C} \cdot \mathrm{min}^{-1}$ ) was represented by two reactions (confirmed by two peaks). Decomposition of the cellulose for $\beta=5^{\circ} \mathrm{C} \cdot \mathrm{min}^{-1}$ took place approximately from $353^{\circ} \mathrm{C}$ to $546{ }^{\circ} \mathrm{C}$. The second stage was detected for $\beta=10^{\circ} \mathrm{C} \cdot \mathrm{min}^{-1}$ and $\beta=20^{\circ} \mathrm{C} \cdot \mathrm{min}^{-1}$, namely, from $400{ }^{\circ} \mathrm{C}$ and $472{ }^{\circ} \mathrm{C}$, respectively. The third stage (lignin fibers decomposition) took place at a wide range of temperature from $200{ }^{\circ} \mathrm{C}$ to $800^{\circ} \mathrm{C}$, in the case of PIS even from $50{ }^{\circ} \mathrm{C}$ to $900{ }^{\circ} \mathrm{C}$. This process was characterized by the slowest weight loss, often during the whole thermal treatment process.

Based on the estimated kinetic parameters, it can be concluded that the Coats-Redfern method may be used as an alternative to other models. The results were comparable with other kinetic description methods. Characterization of specific nut shell residues is recommended for improved modeling of thermal processes and designing of bioreactors for thermal waste treatment. Further research can be continued to optimize the thermal treatment process to achieve expected properties not only for energy purposes but also for other applications, such as biofilters media, sorbents, and other value-added products.

Supplementary Materials: The following are available online at https:/ / www.mdpi.com/1996-107 $3 / 14 / 3 / 682 / s 1$, Table S1. The activation energy $\left(E_{a}\right)$ and pre-exponential $(A)$ of the walnut shells for different conversion rates (reaction order $n=1.5$ ). Table S2. The activation energy $\left(E_{a}\right)$ and preexponential (A) of the hazelnut shells for different conversion rates (reaction order $n=1.5$ ). Table S3. The activation energy $\left(E_{a}\right)$ and pre-exponential (A) of the peanut shells for different conversion rates (reaction order $n=1.5$ ). Table $\mathrm{S} 4$. The activation energy $\left(E_{a}\right)$ and pre-exponential (A) of the pistachio shells for different conversion rates (reaction order $n=1.5$ ).

Author Contributions: Conceptualization, T.N. and A.D.; methodology, T.N.; software, T.N.; validation, T.N., A.D. and J.A.K.; formal analysis, T.N.; investigation, T.N.; resources, T.N.; data curation, T.N.; writing—original draft preparation, T.N.; writing—review and editing, A.D. and J.A.K.; visualization, T.N., A.D. and J.A.K.; supervision, A.D. and J.A.K.; funding acquisition, A.D. and J.A.K. All authors have read and agreed to the published version of the manuscript.

Funding: This manuscript is an effect of the international scholarship exchange of a PhD candidate at Iowa State University funded by NAWA PROM Program (Polish National Agency for Academic 
Exchange). This research received no external funding. The APC was funded by the Department of Applied Bioeconomy of the Wroclaw University of Environmental and Life Sciences and Waste Biomass Valorization Group of the Wroclaw University of Environmental and Life Sciences. In addition, this research was partially supported by the Iowa Agriculture and Home Economics Experiment Station, Ames, Iowa. Project no. IOW05556 (Future Challenges in Animal Production Systems: Seeking Solutions through Focused Facilitation) sponsored by Hatch Act and State of Iowa funds (J.A.K.).

Institutional Review Board Statement: Not applicable.

Informed Consent Statement: Not applicable.

Data Availability Statement: Data sharing not applicable.

Conflicts of Interest: The author declares no conflict of interest.

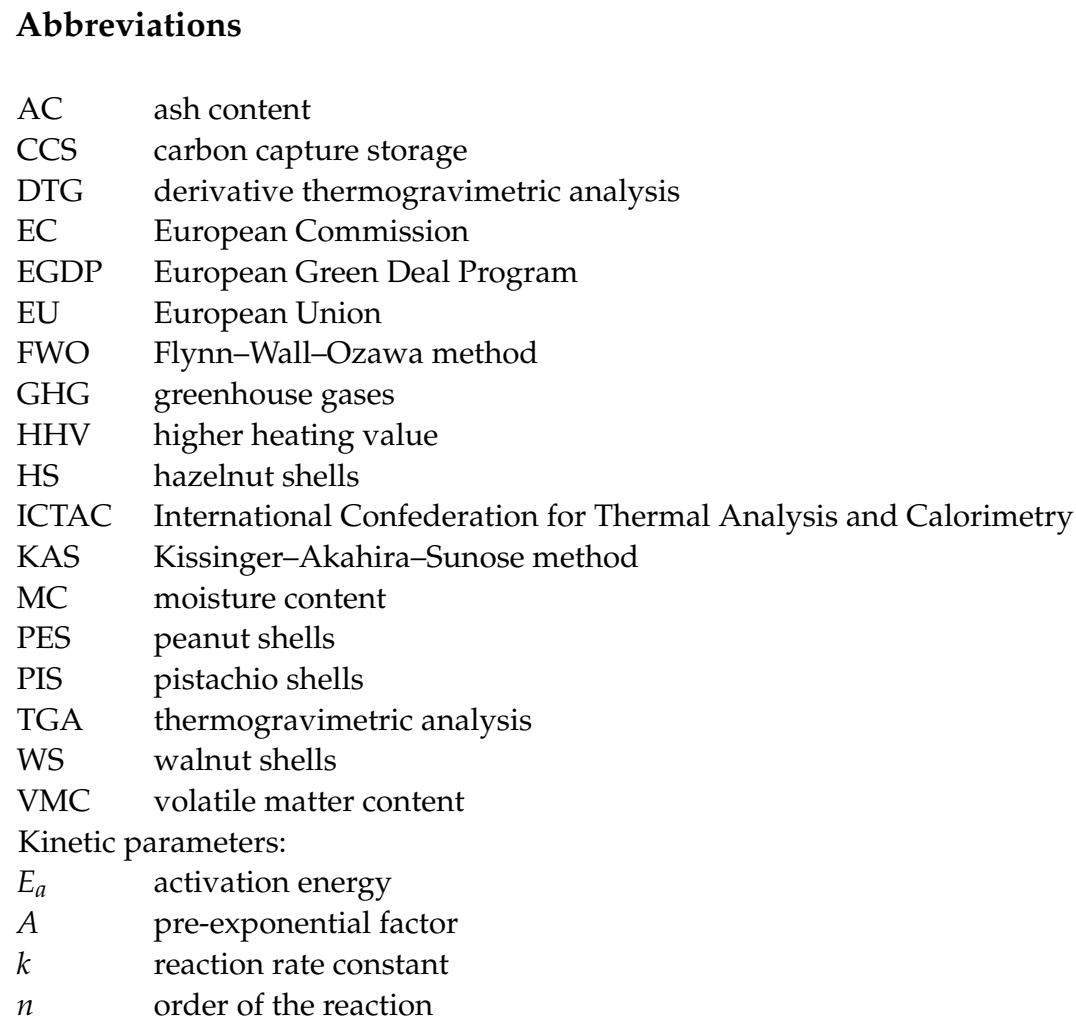

\section{References}

1. European Commission. The European Green Deal; European Commission: Brussels, Belgium, 2019. Available online: https: / / ec.europa.eu/info/sites/info/files/european-green-deal-communication_en.pdf (accessed on 6 December 2020).

2. Tzelepi, V.; Zeneli, M.; Kourkoumpas, D.-S.; Karampinis, E.; Gypakis, A.; Nikolopoulos, N.; Grammelis, P. Biomass Availability in Europe as an Alternative Fuel for Full Conversion of Lignite Power Plants: A Critical Review. Energies 2020, 13, 3390. [CrossRef]

3. Pouikli, K. Towards mandatory Green Public Procurement (GPP) requirements under the EU Green Deal: Reconsidering the role of public procurement as an environmental policy tool. ERA Forum 2020, 21, 699-721. [CrossRef]

4. Catuti, M.; Elkerbout, M.; Alessi, M.; Egenhofer, C. Biomass and Climate Neutrality. In CEPS Policy Insights; CEPS: Brussels, Belgium, 2020.

5. Scherhaufer, S.; Moates, G.; Hartikainen, H.; Waldron, K.; Obersteiner, G. Environmental impacts of foof waste in Europe. Waste Manag. 2018, 77, 980113. [CrossRef] [PubMed]

6. European Commission. Estimates of European Food Waste Levels, Fusions Eu Project; European Commission: Stockholm, Sweden, 2016; ISBN 978-91-88319-01-2.

7. Sharma, R.; Oberoi, H.S.; Dhillon, G.S. Chapter 2-Fruit and Vegetable Processing Waste: Renewable Feed Stocks for Enzymes Production. In Agro-Industrial Wastes as Feedstock for Enzyme Production; Academic Press: Cambridge, MA, USA, 2016; ISBN 9780128023921.

8. Food and Agricultural Organization of United Nations. Statistical Database. 2018. Available online: http://www.fao.org/faostat/ en/\#data/QC (accessed on 4 December 2020). 
9. Razavi, S.M.A.; Rafe, A.; Moghaddam, T.M.; Amini, A.M. Physical properties of pistachio nut and its kernel as a function of moisture content and variety. Part II. Gravimetrical properties. J. Food. Eng. 2007, 81, 226-235. [CrossRef]

10. Dyjakon, A.; Noszczyk, T.; Smędzik, M. The Influence of Torrefaction Temperature on Hydrophobic Properties of Waste Biomass from Food Processing. Energies 2019, 12, 4609. [CrossRef]

11. Dyjakon, A.; Noszczyk, T. Alternative Fuels from Forestry Biomass Residue: Torrefaction Process of Horse Chestnuts, Oak Acorns, and Spruce Cones. Energies 2020, 13, 2468. [CrossRef]

12. Niu, Y.; Lv, Y.; Lei, Y.; Liu, S.; Liang, Y.; Wang, D.; Hui, S. Biomass torrefaction: Properties, applications, challenges, and economy. Renew. Sustain. Energy Rev. 2019, 115, 109395. [CrossRef]

13. Kanwal, S.; Chaudhry, N.; Munir, S.; Sana, H. Effect of torrefaction conditions on the physicochemical characterization of agricultural waste (sugarcane bagasse). Waste Manag. 2019, 88, 280-290. [CrossRef]

14. Poudel, J.; Ohm, T.I.; Oh, S.C. A study on torrefaction of food waste. Fuel 2015, 140, 275-281. [CrossRef]

15. Tursunov, O.; Dobrowolski, J.; Zubek, K.; Czerski, G.; Grzywacz, P.; Dubert, F.; Lapczynska-Kordon, B.; Klima, K.; Handke, B. Kinetic Study of the Pyrolysis and Gasification of Rosa Multiflora and Miscanthus Giganteus Biomasses via Thermogravimetric. Anal. Therm. Sci. 2018, 22, 3057-3071. [CrossRef]

16. Khir, R.; Pan, Z.; Atungulu, G.G.; Thompson, J.F.; Shao, D. Size and Moisture Distribution characteristics of Walnut and Their Components. Food Bioprocess. Technol. 2013, 6, 771-782. [CrossRef]

17. Perea-Moreno, M.A.; Manzano-Agugliaro, F.; Hernandez-Escobedo, Q.; Perea-Moreno, A.J. Peanut Shell for Energy: Properties and its Potential to Respect the Environment. Sustainability 2018, 10, 3254. [CrossRef]

18. Apaydin-Vrol, E.; Putun, E.; Putun, A.E. Slow Pyrolysis of pistachio shell. Fuel 2007, 86, 1892-1899. [CrossRef]

19. Turan, A.; Islam, A. Effect of Drying Methods on Some Chemical Characteristics of Hazelnuts (Corylus avellana L.) during storage. J. Inst. Sci. Tech. 2018, 8, 11-19. [CrossRef]

20. Heydari, M.; Rahman, M.; Gupta, R. Kinetic Study and Thermal Decomposition Behavior of Lignite Coal. Int. J. Chem. Eng. 2015, 2015, 481739. [CrossRef]

21. Via, B.K.; Adhikari, S.; Taylor, S. Modeling for proximate analysis and heating value of torrefied biomass with vibration spectroscopy. Bioresour. Technol. 2013, 133, 1-8. [CrossRef]

22. Burhenne, L.; Messmer, J.; Aicher, T.; Laborie, M.P. The effect of the biomass components lignin, cellulose and hemicellulose on TGA and fixed bed pyrolysis. J. Anal. Appl. Pyrolysis 2013, 101, 177-184. [CrossRef]

23. Quan, C.; Gao, N.; Song, Q. Pyrolysis of biomass components in a TGA and a fixed-bed reactor: Thermochemical behaviors, kinetics, and product characterization. J. Anal. Appl. Pyrol. 2016, 121, 84-92. [CrossRef]

24. Lv, D.; Xu, M.; Liu, X.; Zhan, Z.; Li, Z.; Yao, H. Effect of cellulose, lignin, alkali and alkaline earth metallic species on biomass pyrolysis and gasification. Fuel Process. Technol. 2010, 91, 903-909. [CrossRef]

25. Verhegyi, G.; Antal, M.J.; Jakab, E.; Szabo, P. Kinetic modeling of biomass pyrolysis. J. Anal. Appl. Pyrolysis 1997, $42,73-87$. [CrossRef]

26. Yang, H.; Yan, R.; Chen, H.; Lee, D.H.; Zheng, C. Characteristics of hemicellulose, cellulose and lignin pyrolysis. Fuel 2007, 86, 1781-1788. [CrossRef]

27. Zhou, H.; Long, Y.; Meng, A.; Chen, S.; Li, Q.; Zhang, Y. A novel method for kinetics analysis of pyrolysis of hemicellulose, cellulose, and lignin in TGA and macro-TGA. RSC Adv. 2015, 34, 26509-26516. [CrossRef]

28. Lu, C.; Song, W.; Lin, W. Kinetics of biomass catalytic pyrolysis. Biotechnol. Adv. 2009, 27, 583-587. [CrossRef] [PubMed]

29. Singh, R.K.; Bijayani, B.; Sachin, K. Determination of Activation Energy from Pyrolysis of Paper Cup Waste Using Thermogravimetric Analysis. Res. J. Recent Sci. 2013, 2, 177-182.

30. Arenas, C.N.; Navarro, M.V.; Martinez, J.D. Pyrolysis kinetics of biomass wastes using isoconversional methods and the distributed activation energy model. Bioresour. Technol. 2019, 288, 121485. [CrossRef] [PubMed]

31. Aboyade, A.O.; Hugo, T.J.; Carrier, M.; Meyer, E.L.; Stahl, R.; Knoetze, J.H.; Gorgens, J.F. Non-isothermal kinetic analysis of the devolatilization of corn cobs and sugar cane bagasse in an inert atmosphere. Thermochim. Acta 2011, 517, 81-89. [CrossRef]

32. Paik, P.; Kar, K.K. Thermal degradation kinetics and estimation of life time of polyethylene particles: Effects of particle size. Mater. Chem. Phys. 2009, 113, 953-961. [CrossRef]

33. Lisowski, A.; Pajor, M.; Świętochowski, A.; Dąbrowska, M.; Klonowski, J.; Mieszkalski, L.; Ekielski, A.; Stasiak, M.; Piątek, M. Effects of moisture content, temperautre, and die thickness on the compaction proces, and the density and strength of walnut shell pellet. Renew. Energy 2019, 141, 770-781. [CrossRef]

34. Antmen, Z.F. Exploitation of peanut and hazelnut shells as agricultural industrial wastes for solid biofuel production. Fresenius Environ. Bull. 2019, 28, 2340-2347.

35. Cardozo, E.; Erlich, C.; Alejo, L.; Fransson, T.H. Combustion of agricultural residues: An experimental study for small-scale applications. Fuel 2014, 115, 778-787. [CrossRef]

36. Bonelli, P.R.; Della Rocca, P.A.; Cukierman, A.L. Effect of pyrolysis temperature on composition, surface properties and thermal degradation rates of Brazil Nut shells. Bioreesour. Technol. 2001, 76, 15-22. [CrossRef]

37. Demirbas, Y. Effect of temperature on pyrolysis products from four nut shells. J. Anal. Appl. Pyrol. 2006, 76, 285-289. [CrossRef]

38. Acikalin, K.; Karaca, F.; Bolat, E. Pyrolysis of Pistachio shell: Effects of pyrolysis conditions and analysis of products. Fuel 2012, 95, 169-177. [CrossRef] 
39. Lua, A.C.; Guo, T.Y.J. Effects of pyrolysis conditions on the properties of activated carbons prepared from pistachio-nut shells. Pyrolysis 2004, 72, 279-287. [CrossRef]

40. Haykiri-Acma, H.; Yaman, S.; Kucukbayrak, S. Effects of torrefaction on lignin-rich biomass (hazelnut shell): Structural variations. J. Renew. Sustain. Energy 2017, 9, 063102. [CrossRef]

41. Kasiri, N.; Fathi, M. Production of cellulose nanocrystals from pistachio shells and their application for stabilizing Pickering emulsions. Int. J. Biol. Macromol. 2018, 106, 1023-1031. [CrossRef]

42. Hemmati, F.; Jafari, S.M.; Kashaninejad, M.; Motlagh, M.B. Synthesis and characterization of cellulose nanocrystals derived from walnut shell agricultural residues. Int. J. Biol. Macromol. 2018, 120, 1216-1224. [CrossRef]

43. Cepeliogullar, Ö.; Haykiri-Acma, H.; Yaman, S. Kinetic modeling of RDF pyrolysis: Model-fitting and model free approaches. Waste Manag. 2016, 48, 275-284. [CrossRef]

44. Vyazovkin, S.; Burnham, A.K.; Criado, J.M.; Perez-Maqueda, L.A.; Popescu, C.; Sbirrazzuoli, N. ICTAC Kinetics Committee recommendations for performing kinetic computations on thermal analysis data. Thermochim. Acta 2011, 520, 1-19. [CrossRef]

45. Rueda-Ordonez, Y.J.; Tannous, K. Isoconversional kinetic study of the thermal decompositions of sugarcane straw for thermal conversion processes. Bioresour. Technol. 2015, 196, 136-144. [CrossRef]

46. Khan, Z.; Yusup, S.; Ahmad, M.M.; Uemura, Y.; Chok, V.S.; Rashid, U.; Inayat, A. Kinetic Study on Palm Oil Waste Decomposition. In Biofuel's Engineering Process Technology; InTech: Rijeka, Croatia, 2011.

47. Vasudev, V.; Ku, X.; Lin, J. Kinetic study and pyrolysis characteristics of algal and lignocellulosic biomasses. Bioresour. Technol. 2019, 288, 121496. [CrossRef] [PubMed]

48. Mallick, D.; Bora, B.J.; Barbhuiya, S.A.; Banik, R.; Garg, J.; Sarma, R.; Gogoi, A.K. Detailed Study of Pyrolysis Kinetics of Biomass Using Thermogravimetric Analysis. AIP Conf. Proc. 2019, 2091, 020014.

49. Cai, J.; Bi, L. Precision of the Coats and Redfern Method for the Determination of the Activation Energy without Neglecting the Low-Temperature End of the Temperature Integral. Energy Fuel 2008, 22, 2172-2174. [CrossRef]

50. Kahrizsangi, R.; Abbasi, M.H. Evaluation of reliability of Coats-Redfern method for kinetic analysis of non-isothermal TGA. Trans. Nonferrous Met. Soc. China 2008, 18, 217-221.

51. Parascanu, M.M.; Sandoval-Salas, F.; Soreanu, G.; Valverde, J.L.; Sanchez-Silva, L. Valorization of Mexican biomasses through pyrolysis, combustion, and gasification processes. Reviews 2017, 71, 509-522. [CrossRef]

52. Barzegar, R.; Yozgatligil, A.; Olgun, H.; Atimtay, A.T. TGA and kinetic study of different torrefaction conditions of wood biomass under air and oxy-fuel combustion atmospheres. J. Energy Inst. 2020, 93, 889-898. [CrossRef]

53. Gronli, M.G.; Varhegyi, G.; Blasi, C.D. Thermogravimetric analysis and devolatilization kinetics of wood. Ind. Eng. Chem. Res. 2002, 41, 4201-4208. [CrossRef]

54. Kaltschmitt, M.; Streicher, W. Energie aus Biomasse. Regenerative Energien in Österreich; Springer Vieweg: Wiesbaden, Germany, 2009.

55. Blasi, C.D. Modeling chemical and physical processes of wood and biomass pyrolysis. Prog. Energy Combust. Sci. 2008, 34, 47-90.

56. Wang, J.; Shen, B.; Kang, D.; Yuan, P.; Wu, C. Investigate the interactions between biomass components during pyrolysis using in-situ DRIFTS and TGA. Chem. Eng. Sci. 2019, 195, 767-776. [CrossRef]

57. Yeo, J.Y.; Chin, B.L.F.; Tan, J.K.; Loh, Y.S. Comparative studies on the pyrolysis of cellulose, hemicellulose, and lignin based on combined kinetics. J. Energy Inst. 2019, 92, 27-37. [CrossRef]

58. Senneca, O.; Cerciello, F.; Russo, C.; Wutscher, A.; Muhler, M.; Apicella, B. Thermal treatment of lignin, cellulose and hemicellulose in nitrogen and carbon dioxide. Fuel 2020, 271, 117656. [CrossRef]

59. Jewiarz, M.; Wróbel, M.; Mudryk, K.; Szufa, S. Impact of the Drying Temperature and Grinding Technique on Biomass Grindability. Energies 2020, 13, 3392. [CrossRef]

60. Wróbel, M.; Jewiarz, M.; Mudryk, K.; Knapczyk, A. Influence of Raw Material Drying Temperature on the Scots Pine (Pinus sylvestris L.) Biomass Agglomeration Process-A Preliminary Study. Energies 2020, 13, 1809.

61. Kocabas-Atakh, Z.O.; Okyay-Oner, F.; Yurum, Y. Combustion characteristics of Turkish hazelnut shell biomass, lignite coal, and their respective blends via thermogravimetric analysis. J. Therm. Anal. Calorim. 2014, 119, 1723-1729. [CrossRef]

62. Haykiri-Acma, H. The role of particle size in the non-isothermal pyrolysis of hazelnut shell. J. Anal. Appl. Pyrol. 2006, 75, 211-216. [CrossRef]

63. Demirbas, A. Kinetics for non-isothermal flash pyrolysis of hazelnut shell. Bioresour. Technol. 1998, 66, 247-252. [CrossRef]

64. Acikalin, K. Thermogravimetric analysis of walnut shell as pyrolysis feedstock. J. Therm. Anal. Calorim. 2011, 105, 145-150. [CrossRef]

65. Acikalin, K. Pyrolytic characteristics and kinetics of pistachio shell by thermogravimetric analysis. J. Therm. Anal. Calorim. 2012, 109, 227-235. [CrossRef]

66. Tasar, S.; Kaya, F.; Ozer, A. Biosorption of lead (II) ions from aqueous solution by peanut shells: Equilibrium, thermodynamic and kinetic studies. J. Environ. Chem. Eng. 2014, 2, 1018-1026. [CrossRef] 